\title{
A Role for All-Trans-Retinoic Acid in the Early Steps of Lymphatic Vasculature Development
}

\author{
Daniela Marino $^{a}$ Vasilios Dabouras ${ }^{a}$ André W. Brändlia, b Michael Detmar $^{a}$ \\ anstitute of Pharmaceutical Sciences, Department of Chemistry and Applied Biosciences, Swiss Federal \\ Institute of Technology (ETH Zurich), Zurich, Switzerland; b Walter-Brendel-Centre of Experimental Medicine, \\ Ludwig-Maximilians-University, Munich, Germany
}

\section{Key Words}

Retinoids - Lymphangiogenesis • Prox $1 \cdot$ LYVE-1

Embryonic stem cells $\cdot$ Xenopus laevis

\begin{abstract}
The molecular mechanisms that regulate the earliest steps of lymphatic vascular system development are unknown. To identify regulators of lymphatic competence and commitment, we used an in vitro vascular assay with mouse embryonic stem cell-derived embryoid bodies (EBs). We found that incubation with retinoic acid (RA) and, more potently, with RA in combination with CAMP, induced the expression of the lymphatic competence marker LYVE-1 in the vascular structures of the EBs. This effect was dependent on RA receptor (RAR)- $\alpha$ and protein kinase A signaling. RA-cAMP incubation also promoted the development of CD31+/LYVE-1+/Prox1+ cell clusters. In situ studies revealed that RAR- $\alpha$ is expressed by endothelial cells of the cardinal vein in ED 9.5-11.5 mouse embryos. Timed exposure of mouse and Xenopus embryos to excess of RA upregulated LYVE-1 and VEGFR-3 on embryonic veins and increased formation of Prox1-positive lymphatic progenitors. These findings indicate that RA signaling mediates the earliest steps of lymphatic vasculature development.

Copyright $\odot 2010$ S. Karger AG, Basel
\end{abstract}

\section{Introduction}

The lymphatic vascular system has an important role in the maintenance of tissue fluid homeostasis, intestinal lipid absorption and immune surveillance in that it recruits and transports immune cells from peripheral tissues to the regional lymph nodes $[1,2]$. There have been many studies into the role of the lymphatic system in promoting metastasis to lymph nodes and beyond [3-5], and in modulating inflammatory diseases $[6,7]$. Much progress has been made following the identification of specific lymphatic markers that distinguish lymphatic endothelial cells from blood vascular endothelial cells and novel molecular mediators of lymphatic vessel growth and differentiation, as well as developmental studies in mouse models $[1,2]$.

There is considerable evidence that during mammalian embryonic development, the lymphatic vascular system predominantly develops from pre-existing embryonic veins. In mice, expression of the lymphatic vessel endothelial hyaluronan receptor-1 (LYVE-1) at embryonic day (ED) 9-9.5 by the endothelial cells that line the anterior cardinal veins is considered to be the first morphological indication that venous endothelial cells have acquired the competence to respond to an unidentified lymphatic-inducing signal [8]. The biological function of

Dr. Michael Detmar

Institute of Pharmaceutical Sciences

Swiss Federal Institute of Technology, ETH Zurich

Wolfgang-Pauli-Str. 10, HCI H303, CH-8093 Zurich (Switzerland)

Tel. +41 44633 7361, Fax +41 44633 1364,E-Mail michael.detmar@pharma.ethz.ch 
LYVE-1 is unknown; LYVE-1-deficient mice have no major lymphatic or other abnormalities $[9,10]$. At approximately ED 9.5, a restricted subpopulation of endothelial cells on one side of the cardinal vein expresses the transcription factor Prox-1, indicating that this is the stage of lymphatic commitment [11]. These Prox1-positive cells then bud off from the cardinal veins and migrate away to finally form the primitive lymph sacs. Prox1-deficient mice completely lack a lymphatic vascular system [11]. Vascular budding and migration appear to occur under the guidance of local gradients of vascular endothelial growth factor (VEGF)-C, which activates its receptor, VEGFR-3, on lymphatic precursor cells [12]. VEGF-Cdeficient mice also lack lymphatic vasculature and undergo prenatal death because of pronounced fluid accumulation in the tissues [12]. It was recently shown that the transcription factor Sox 18 is expressed in a subset of the cardinal vein cells that later become Prox1-positive lymphatic progenitor cells and that Sox 18 directly activates Prox1 transcription [13].

Studies in genetic mouse models indicate that following the formation of the lymph sacs, the separation of the lymphatic and venous system is mediated by the tyrosine kinase Syk and the adaptor protein SLP-76 [14, 15], the sprouty-related ena/VASP homology 1 domain-containing proteins (spred) 1 and 2 [16], and angiopoietin-like protein 4 [17]. Further lymphatic vessel maturation and remodeling are controlled by a plethora of molecules [for review, see 2] that includes the transcription factor Foxc2 [18], angiopoietin-2 $[19,20]$, the non-kinase receptor neuropilin-2 [21], ephrin B2 [22] and the transmembrane glycoprotein podoplanin [23].

Despite advances in our understanding of lymphatic vasculature development, the molecular mechanisms that control the earliest stages of lymphatic competence (expression of LYVE-1 by endothelial cells of the cardinal vein and lymphatic precursor cells) have not been determined. To identify pathways that mediate lymphatic competence, we used a previously established embryoid body (EB)-based vascular differentiation assay [24] as a screening model. This system assesses the ability of mouse EB cells to differentiate into lymphatic vessel-like structures that express the panvascular marker CD31, as well as Prox1 and LYVE-1 [24]; it was previously used to characterize the ability of VEGF-C to promote in vitro lymphangiogenesis $[24,25]$. Using this model system, we investigated the potential effects of soluble factors that have been previously reported to be potentially associated with activity on lymphatic endothelial cells in vitro or in vivo. We also investigated the effects of retinoic acid
(RA), since RA has been shown to be involved in a plethora of developmental differentiation processes, including vascular differentiation [26-28].

In our study, the growth factors VEGF-C, growth hormone, insulin-like growth factor (IGF)-1 and interleukin (IL)-7 were found to moderately induce the expression of LYVE-1 in EBs. Incubation of EBs with RA and, more potently, a combination of RA and cyclic AMP (cAMP), induced LYVE-1 expression in the vascular structures; this effect depended on RA receptor (RAR)- $\alpha$ and protein kinase A (PKA) signaling. In situ studies revealed that RAR- $\alpha$ is highly expressed by endothelial cells of the cardinal vein from ED 9.5-11.5 in mice, in areas of LYVE1 expression. Most importantly, timed exposure of mouse embryos and of Xenopus laevis tadpoles to RA resulted in potent upregulation of LYVE-1 and VEGFR-3 on embryonic veins and lymph sacs. Together, these findings indicate that RA signaling could mediate the earliest steps of lymphatic vasculature development.

\section{Materials and Methods}

Mouse Embryonic Stem Cell Culture, Establishment and Treatment of EBs

Murine C57BL/6x129SvEv-derived (passage 3-12) embryonic stem cells (kindly provided by N. Gale, Regeneron Pharmaceuticals, Tarrytown, N.Y., USA) were cultured on mitotically inactivated primary mouse embryonic fibroblasts (passage 2-5; Institute of Laboratory Animal Science, University of Zurich, Switzerland) in Dulbecco's modified Eagle medium (Gibco, Eggenstein, Germany), supplemented with $18 \%$ fetal bovine serum (Gibco), $100 \mathrm{nM}$ sodium pyruvate (Sigma, Buchs, Switzerland), MEM vitamins, $2 \mathrm{~mm}$ L-glutamine, streptomycin and penicillin (all from Gibco), $10 \mathrm{mM}$ 2-mercaptoethanol and 2,000 U/ml recombinant leukemia inhibitory factor (LIF; Chemicon International, Temecula, Calif., USA). Primary mouse embryonic fibroblasts and LIF were removed and murine embryonic stem cells were transferred to suspension culture for EB formation as described [29]. After 3 or 4 days, EBs of the same size (approximately $500 \mu \mathrm{m}$ in diameter) were transferred into 12 -well dishes (1 EB per well; BD Bioscience, San Diego, Calif., USA) and cultured for 14 days without LIF. Then, EBs were incubated with or without the following factors for 2, 4, 6, 8, 10, 12 or 14 days: $20 \mathrm{ng} / \mathrm{ml}$ recombinant human VEGF-A (VEGF-A 165; kindly provided by the National Cancer Institute, Bethesda, Md., USA); $200 \mathrm{ng} / \mathrm{ml}$ recombinant human VEGF-C (R\&D Systems, Minneapolis, Minn., USA); 20 $\mathrm{ng} / \mathrm{ml}$ human fibroblast growth factor-2 (kindly provided by the National Cancer Institute); $1 \mathrm{mg} / \mathrm{ml}$ hyaluronic acid sodium salt from human umbilical cord (Fluka, Buchs, Switzerland); $100 \mathrm{ng} /$ $\mathrm{ml}$ recombinant human IGF-1 (R\&D Systems); $25 \mathrm{ng} / \mathrm{ml}$ recombinant human IL-3 (Chemicon International); $30 \mathrm{ng} / \mathrm{ml}$ human hepatocyte growth factor (R\&D Systems); $20 \mathrm{ng} / \mathrm{ml}$ human platelet growth factor (R\&D Systems); $50 \mathrm{ng} / \mathrm{ml}$ human growth hormone (R\&D Systems); $20 \mathrm{ng} / \mathrm{ml}$ recombinant human IL-7 (Chem- 
icon International); $100 \mu \mathrm{M}$ S-nitroso-N-acetylpenicillamine (Sigma); $10 \mathrm{~mm}$ human endothelin-3 (R\&D Systems); 1, 2.5, 5, 10 or $100 \mu \mathrm{M}$ all-trans-RA (Sigma); $10 \mu \mathrm{M}$ 4-[E-2-(5,6,7,8-tetrahydro-5, 5, 8,8-tetramethyl-2-naphthalenyl)-1-propenyl]benzoic acid (Sigma); 1 or $10 \mu \mathrm{M}$ 13-cis-RA (Sigma); $0.5 \mathrm{~mm} \mathrm{~N}-6,2^{\prime}$-Odibutyryl-adenosine $3^{\prime}, 5^{\prime}$-cyclic monophosphate (cAMP; Fluka); $10 \mu \mathrm{M}$ Ro 41-5253 (BioMol International, Plymouth Meeting, Pa., USA); $10 \mu \mathrm{M} \mathrm{N}$-[2-(p-bromocinnamylamino)ethyl]-5-isoquinoline sulfonamide, Di-HCl salt (H89; Calbiochem, San Diego, Calif., USA). EBs were fixed in $-20^{\circ} \mathrm{C}$ cold $100 \%$ methanol or in $4 \%$ paraformaldehyde at $4^{\circ} \mathrm{C}$ for $10 \mathrm{~min}$.

\section{Endothelial Cell Culture, Real-Time RT-PCR, FACS and Immunostains}

Human umbilical vein endothelial cells (HUVECs), obtained from ScienceCell Research Labs (San Diego, Calif., USA) were seeded into fibronectin-coated culture dishes $(10 \mu \mathrm{g} / \mathrm{ml}$; BD Biosciences, Bedford, Mass., USA) and were cultured in endothelial cell basal medium (Cambrex Bio Science, Walkersville, Md., USA) supplemented with $20 \%$ fetal bovine serum (Invitrogen, Grand Island, N.Y., USA), 2 mM L-glutamine, antibiotic-antimycotic solution, $10 \mu \mathrm{g} / \mathrm{ml}$ hydrocortisone and N-6,2'-O-dibutyryladenosine $3^{\prime}, 5^{\prime}$-cyclic monophosphate ( $25 \mu \mathrm{g} / \mathrm{ml}$; all from Fluka). Cells from passages 6-10 were used. HUVECs were incubated for $24 \mathrm{~h}$ with $10 \mu \mathrm{M}$ RA plus $0.5 \mathrm{mM}$ cAMP or with DMSO as negative control. Then real-time RT-PCR, FACS and immunostaining were performed. For real-time RT-PCR analyses, total cellular RNA was isolated using the Trizol reagent (Invitrogen) and was extracted with chloroform, precipitated with isopropanol, washed with $70 \%$ ethanol, and dissolved in DNase-free/RNase-free distilled water. The concentration of RNA was measured using a NanoDrop ND-1000 spectrophotometer (Witec AG, Littau, Switzerland). The expression of LYVE-1 and Prox1 mRNA was quantified by TaqMan real-time RT-PCR using the AB 7900 HT fast real-time PCR system (Applied Biosystems, Foster City, Calif., USA). The following probes and primers were used: LYVE-1 forward primer (FP) 5'-AGCTATGGCTGGGTTGGAGA-3', reverse primer (RP) 5'-CCCCATTTTTCCCACACTTG-3', probe 5'-FAM-TTCGTGGTCATCTCTAGGATTAGCCCAAACCBKH1-3'; Prox1: FP 5'-ACAAAAATGGTGGCACGGA-3', RP 5'CCTGATGTACTTCGGAGCCTG-3', probe 5'-FAM-CCCAGTTTCCAAGCCAGCGGTCTCT-BKH1-3'. Each reaction was normalized for the expression of $\beta$-actin (FP $5^{\prime}$-TCACCGAGCGCGGCT-3', RP 5'-TAATGTCACGCACGATTTCCC-3', probe 5'-JOE-CAGCTTCACCACCACGGCCGAG-TAMRA-3'). Student's $t$ test was performed in Office Excel. For FACS analysis, cells were stained with rabbit anti-human LYVE-1 antibody (ReliaTec, Braunschweig, Germany; working concentration: $3 \mu \mathrm{g} /$ $\mathrm{ml}$ ), anti-rabbit fluorescein isothiocyanate or isotype control antibodies (CALTAG/Invitrogen, Basel, Switzerland), and FACS was performed using a BD FACSCanto (BectonDickinson, Basel, Switzerland) and the FACSDiva software. Data were analyzed with Flowjo software (Treestar, Ashland, Tenn., USA). For immunostains, cells were stained with human LYVE-1 antibody (ReliaTec; working concentration $1.5 \mu \mathrm{g} / \mathrm{ml}$ ) and human Prox1 antibody (kindly donated by Prof. K. Alitalo), and corresponding secondary antibodies were labeled with Alexa-Fluor 488 or 594 (Molecular Probes, Eugene, Oreg., USA; working dilution 1:200). Cell nuclei were counterstained with Hoechst bisbenzimide (Sigma). Negative controls using isotype control IgG instead of the primary antibodies showed little or no background staining (data not shown). All experiments were performed three times with comparable results.

\section{Immunofluorescence and Quantitative Analysis of Vessel} Development in EBs

EBs (9 per group) were stained with antibodies against mouse LYVE-1 (Angiobio, Del Mar, Calif., USA; R\&D Systems; working dilution 1:500), CD31 (BD Bioscience; working dilution 1:50) or Proxl (kindly provided by Dr. Kari Alitalo, Helsinki, Finland; working dilution 1:100), and corresponding secondary antibodies were labeled with Alexa-Fluor 488 or 594 (Molecular Probes). Cell nuclei were counterstained with Hoechst bisbenzimide (SigmaAldrich). Negative controls using isotype control IgG instead of the primary antibodies showed little or no background staining (data not shown). LYVE-1/CD31-stained sections were examined with a Zeiss Axiovert 200M microscope, and images were captured with a Zeiss AxioCam-MRm (Carl Zeiss, Oberkochen, Germany). Image acquisition in the individual fluorescent channels was accomplished using Axio Vision 4.4 software (Zeiss). Adobe Photoshop CS3 (Adobe Systems, San Jose, Calif., USA) was used to adjust image brightness and for image overlay. Computer-assisted morphometric vessel analyses were performed using the IP-LAB software (Scanalytics, Fairfax, Va., USA). The total EB area was examined and the total vessel area and the total number of vessels per EB were determined on differential immunofluorescence stains (CD31/LYVE-1). The average vessel area and average vessel number per group were then calculated and statistical analysis was performed using the unpaired Student's t test. Prox1/ LYVE-1/CD31-positive cell cluster imaging and quantification was done with a Delta Vision microscope at $\times 20$, and the 3 -dimensional images were captured with a Roper CoolSnap HQ camera and analyzed with DeltaVision Analysis Software (Applied Precision SoftWoRx, Issaquah, Wash., USA) for deconvolution.

\section{Immunohistochemistry of Mouse Embryo Sections}

FVB mice (12-16 weeks of age; 2 estrous females and 1 male per cage) were allowed to breed overnight. Females with detectable vaginal plugs on the next morning were determined to be at day 0 of pregnancy. Pregnant mice were housed individually. The pregnant mice were sacrificed by $\mathrm{CO}_{2}$ at days 9.5, 10.5 and 11.5 of pregnancy. The embryos were removed by laparotomy. All embryos were immediately fixed in $4 \%$ paraformaldehyde at $4{ }^{\circ} \mathrm{C}$ for $48 \mathrm{~h}$, then dehydrated in ethanol series, cleared in xylene and embedded in paraffin wax. Serial cross-sections $(10 \mu \mathrm{m})$ of the embryos were cut and mounted on glass slides. After they were dewaxed in xylene, sections were hydrated and processed for immunohistochemistry for LYVE-1 (goat biotinylated anti-mouse; R\&D Systems; working dilution 1:10) and RAR- $\alpha$ (rabbit antimouse; Santa Cruz Biotechnology; working dilution 1:50). In additional experiments, RA (Sigma-Aldrich) or Ro 41.5253 (BioMol International) were dissolved in corn oil right before use; pregnant mice (5 per treatment group) were given two intraperitoneal injections of $25 \mathrm{mg} / \mathrm{kg}$ of body weight of RA or of $50 \mathrm{mg} / \mathrm{kg}$ body weight of Ro 41-5253 in corn oil on days 8 and 10 of pregnancy. Control mice $(n=5)$ received an equal volume of corn oil. Mice were sacrificed on day 11.5 of pregnancy. Embryos were embedded in paraffin wax or frozen in OCT (Sakura FineTek, Torrance, Calif., USA). Serial cross-sections of the embryos were cut at a 
thickness of $10 \mu \mathrm{m}$ (paraffin) or $15 \mu \mathrm{m}$ (frozen sections) and were mounted on glass slides. Paraffin sections were processed for LYVE-1 immunohistochemistry as described above. The sections were exposed to AEC (3-amino-9-ethylcarbazole) chromogen that forms a red end product at the site of the antigen and the reaction was stopped after $1 \mathrm{~min}$ incubation. Frozen sections were fixed in $100 \%$ methanol at $-20^{\circ} \mathrm{C}$ for $10 \mathrm{~min}$ and then processed for immunofluorescence staining for Proxl (kindly donated by Prof. K. Alitalo) and CD31 (BD Bioscience), using corresponding secondary antibodies labeled with Alexa-Fluor 488 or 594 (Molecular Probes). Cell nuclei were counterstained with Hoechst bisbenzimide. Negative controls using isotype control IgG instead of the primary antibodies showed little or no background staining (data not shown). The stained sections were examined with a Zeiss Axioskop 2 mot plus. All images were captured with a Zeiss AxioCam-MRm. The quantification of LYVE-1 expression was performed using Photoshop C3; the number of selected LYVE-1stained pixels was determined and their percentage per total pixel number per picture (LYVE-1 area fraction) was then determined. The jugular lymph sac area quantification was performed using the area measurement tool of Photoshop C3. The quantification of CD31+/Prox1+ cells was performed by counting the number of CD31+/Prox1+ cells per picture. Three sections per embryos and 4 embryos from 4 different pregnant mice were analyzed.

\section{$\mathrm{X}$. laevis Embryos and in situ Hybridization}

In vitro fertilization, culture and staging of $X$. laevis embryos (tadpoles) were performed as previously described [30, 31]. Embryos were cultured in $0.1 \times \mathrm{MMR}(0.1 \mathrm{M} \mathrm{NaCl}, 2 \mathrm{mM} \mathrm{KCl}, 1 \mathrm{mM}$ $\mathrm{MgSO}_{4}, 2 \mathrm{mM} \mathrm{CaCl}_{2}, 5 \mathrm{~mm}$ HEPES and $0.1 \mathrm{mM}$ EDTA) at $22^{\circ} \mathrm{C}$ until stage 28 . Thereafter, $20 \mu \mathrm{M}$ RA plus $1 \mathrm{mM}$ cAMP or DMSO was added to the medium. In addition, tadpoles were also bathed with Ro 41-5253 (concentration range $100 \mathrm{nM}$ to $20 \mu \mathrm{M}$ ), but the treatment resulted in lethality within the first $4 \mathrm{~h}$ of exposure. Embryos were fixed at stage 39 in $4 \%$ formalin for $1 \mathrm{~h}$. Probe synthesis, whole-mount in situ hybridization and bleaching of embryos were carried out as described previously [31-33]. For in situ hybridization, probe synthesis, whole-mount in situ hybridization and bleaching of embryos were carried out as described [3133]. Digoxigenin probes were generated from linearized plasmids encoding for LYVE-1, Prox1, VEGFR-3 and CD31. Digital photographs of stained embryos were taken with an AxioCam Color camera mounted on a Zeiss Stereo Lumar.V12 stereoscopic microscope.

\section{Results}

\section{RA Promotes Lymphatic Differentiation of EBs}

We used the EB vascular differentiation assay to identify regulators of the early steps of lymphatic vascular system development [24]. We first investigated the effects of several candidate molecules on the number and size of CD31+/LYVE-1+ vessel-like structures. The factors were added to EBs, starting at day 14 after initiation, for up to 10 days. In accordance with previous results [24, 25],
VEGF-C promoted the formation of CD31+/LYVE-1+ vascular structures, compared with the vehicle control. The maximum induction occurred on day 4 of exposure (data not shown), so this was chosen as the study period for further investigations.

Incubation of EBs with VEGF-C, growth hormone, IGF-1 and IL-7 significantly promoted the expression of LYVE-1 in CD31+ structures (fig. 1a). Incubation of EBs with $10 \mu \mathrm{M}$ RA and, even more potently, with a combination of RA and cAMP, resulted in an enlarged area of CD31+/LYVE-1+ structures, compared to controls (fig. 1a). The cAMP concentration of $0.5 \mu \mathrm{M}$ was chosen based on the results of a previous study in mouse endothelial progenitor cells [34]. Only VEGF-C and RA, with or without CAMP, also significantly promoted the number of CD31+/LYVE-1+ structures (fig. 1b). The effects of $\mathrm{RA}$ at $1 \mu \mathrm{M}$ were less pronounced than at $10 \mu \mathrm{M}$ (data not shown). In contrast, no major effects on the total area or number of CD31+/LYVE-1+ structures were detected after incubation with placental growth factor, hepatocyte growth factor, IL-3 or the nitric oxide donor S-nitroso-Nacetyl-1,1-penicillamine. cAMP did not enhance VEGF-C effect and incubation with cAMP alone had no effect on EBs vasculature (fig. 1a). In agreement with a specific role of retinoic receptors, we found that in addition to RA, 13-cis-RA (+ cAMP) and the synthetic retinoid analogue TTBNP (+ cAMP) also promoted significant formation of LYVE-1+/CD31+ area (fig. 1c).

Incubation of EBs with RA significantly increased the EB area covered by CD31+/LYVE-1+ structures (fig. $2 \mathrm{~d}-$ f) and, in agreement with the documented synergistic effect of RA and cAMP in other systems [34-36], the combination of RA and cAMP for 4 days resulted in LYVE-1 expression by most of the CD31+ endothelial cells (78.6 + $14 \%$; fig. $2 \mathrm{~g}-\mathrm{o}$ ), compared to $27+14 \%$ in control EBs (fig. $2 \mathrm{a}-\mathrm{c}$ ). A quantitative analysis revealed that the RA + cAMP treatment significantly increased the total CD31+ area and the CD31+/LYVE-1+ area, but not the CD31+/ LYVE-1- area, as compared with controls (fig. 2p), thus excluding the possibility that the observed increase in LYVE-1 expression might be a secondary effect due to an overall increased amount of CD31+ vascular structures.

Importantly, incubation of EBs with RA and cAMP for up to 4 days significantly increased the number of Prox1+/LYVE-1+/CD31+ cell clusters formed (fig. $3 \mathrm{e}-\mathrm{j}$; see online supplementary figure $\mathrm{S} 1 \mathrm{E}-\mathrm{H}$, www. karger.com/doi/10.1159/000320620), whereas only a few individual Prox1+/LYVE-1+/CD31+ cells, but no cell clusters, were detected in control EBs (fig. 3a-d, j; online suppl. fig. S1A-D). 


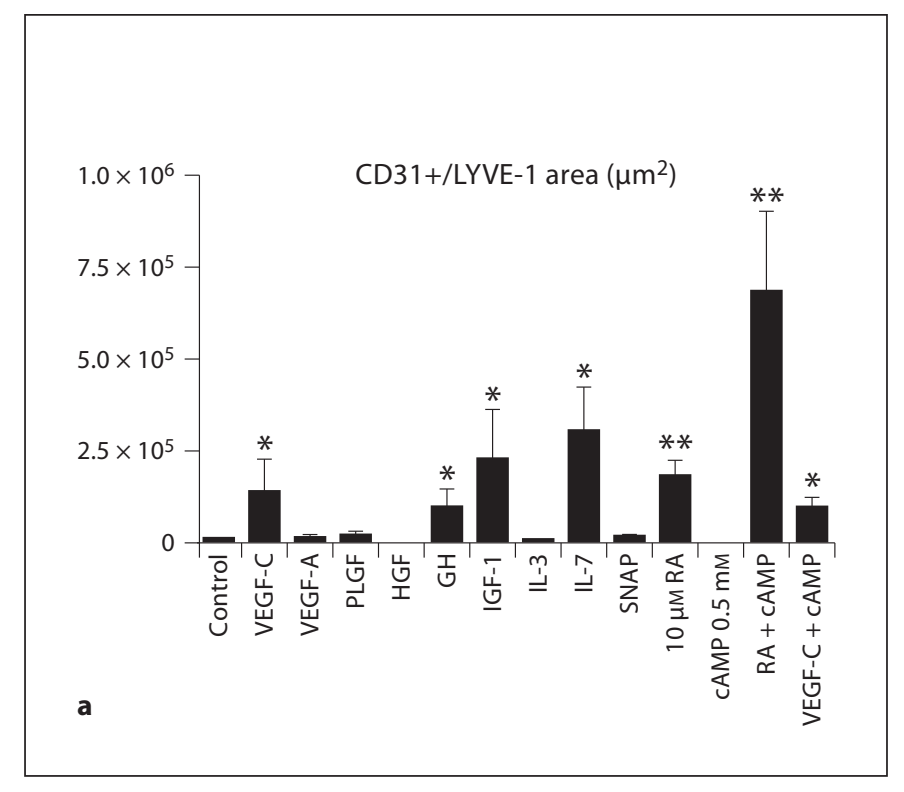

Fig. 1. The in vitro mouse EB assay reveals that RA and CAMP induce LYVE-1 expression. Mouse EBs were cultured for 14 days and were then incubated with compounds for 4 days. $10 \mu \mathrm{M}$ alltrans-RA (RA) and RA + $0.5 \mathrm{mM} \mathrm{cAMP}(\mathrm{RA}+\mathrm{cAMP})$ increased the LYVE-1+ area among CD31+ vessel-like structures (a). VEGFC, IGF-1, GH and IL-7 also showed a significant induction of LYVE-1 expression (a). $10 \mu \mathrm{M}$ all-trans-RA + cAMP and VEGF-C induced the formation of several distinct LYVE1+ lymphatic vessel-like structures (b). 13-cis-RA + cAMP and the synthetic retinoid TTBNP (+ cAMP) increased the area of LYVE-1 expression (c). Exposure of EBs to Ro 41-5253, an inhibitor of RAR- $\alpha$, in combination with RA + cAMP inhibited the expression of LYVE-1 in CD31+ vessel-like structures. H69, an inhibitor of PKA, also inhibited the effects of RA + cAMP. Ro 41-5253 did not significantly inhibit the VEGF-C effect. EBs exposed to the inhibitors alone expressed the same levels of LYVE-1 as controls. Data are expressed as mean values + SEM $(\mathrm{n}=5) .{ }^{*} \mathrm{p}<0.05 ;{ }^{* *} \mathrm{p}<0.01$; *** $\mathrm{p}<0.001$.

Fig. 2. Incubation of EBs with RA and cAMP induces LYVE-1 expression in CD31+ vessel-like structures. Differential immunofluorescence analysis of control EBs for expression of CD31 and LYVE-1 showed the formation of CD31+/LYVE-1- blood vessellike structures, whereas only a few endothelial cells expressed LYVE-1 (a-c). Incubation with RA induced LYVE-1 expression in
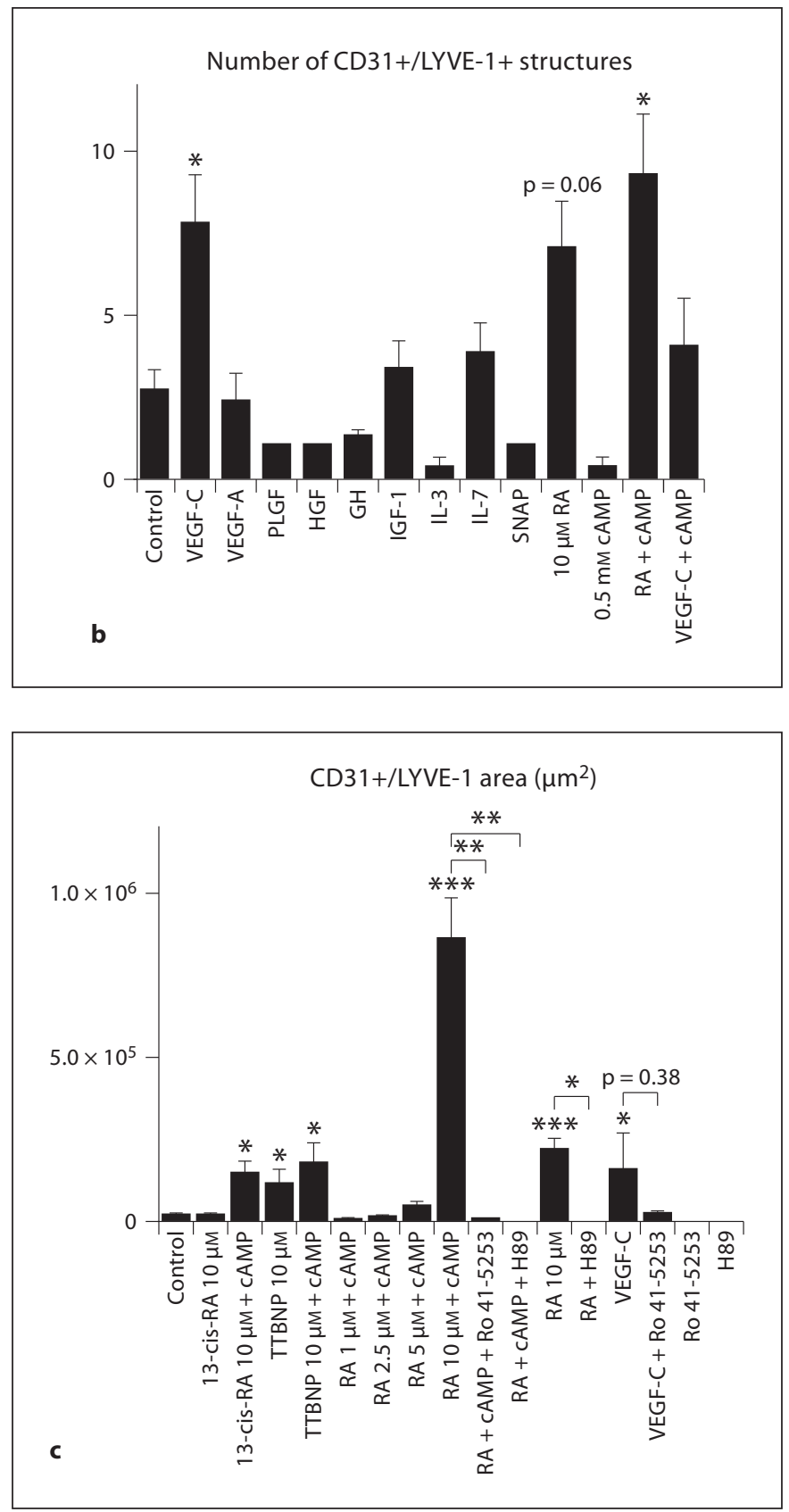

the CD31+ structures (d-f). RA in combination with cAMP (RA + cAMP) further increased the CD31+/LYVE-1+ area (g-p). The total CD31+ and the CD31+/LYVE-1+ area, but not the CD31+/LYVE-1- area was increased (p). Data are expressed as mean values + SEM $(n=9)$. Scale bars $=100 \mu \mathrm{m}$. 

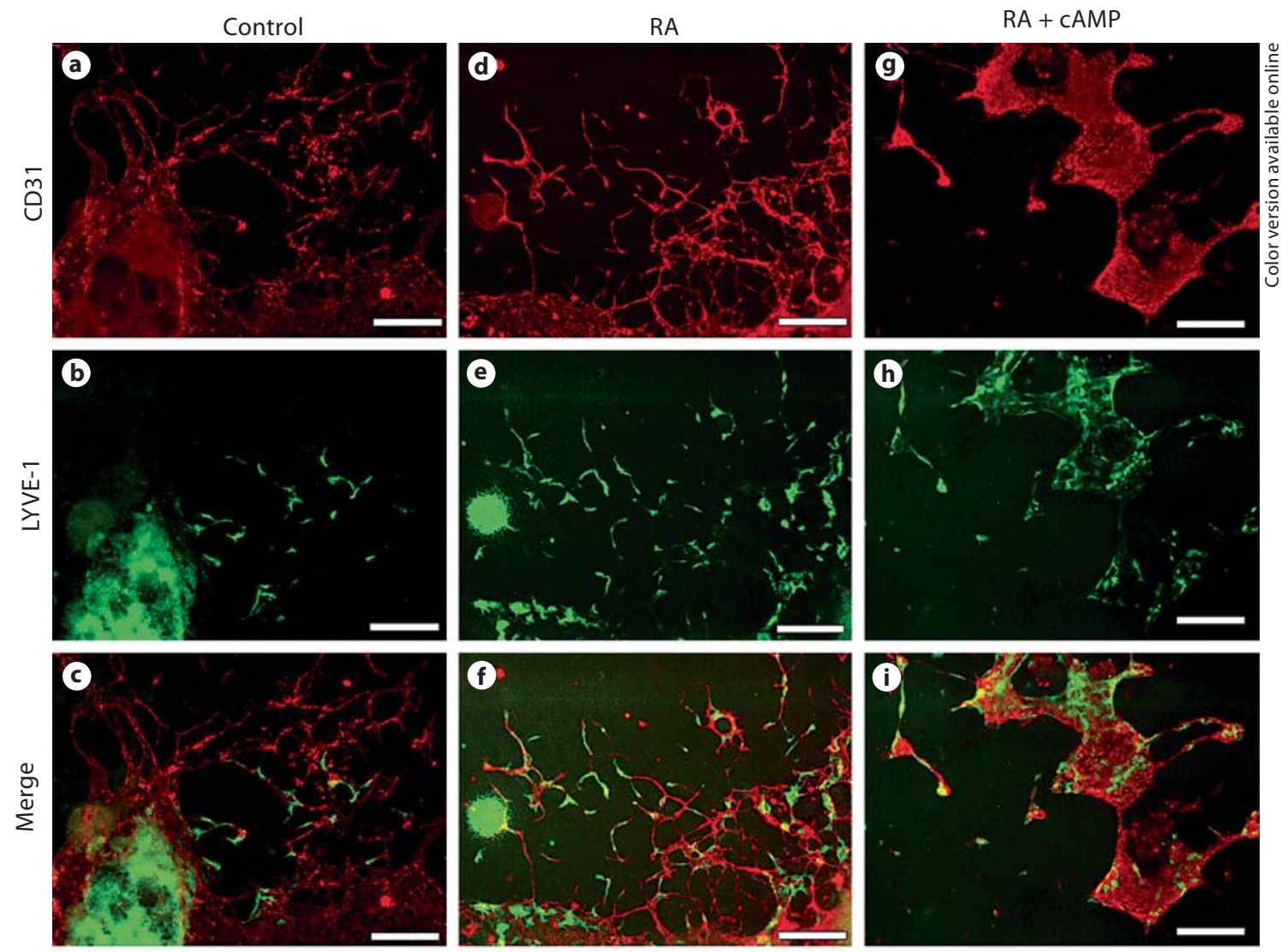

$\mathrm{RA}+\mathrm{CAMP}$

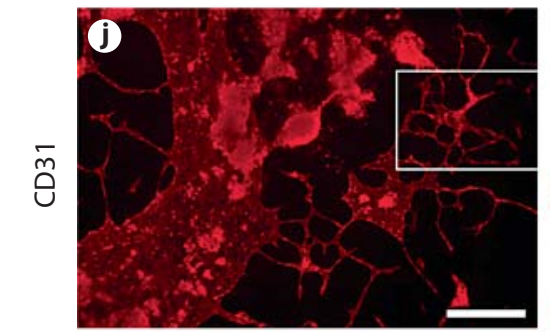

RA + cAMP inset
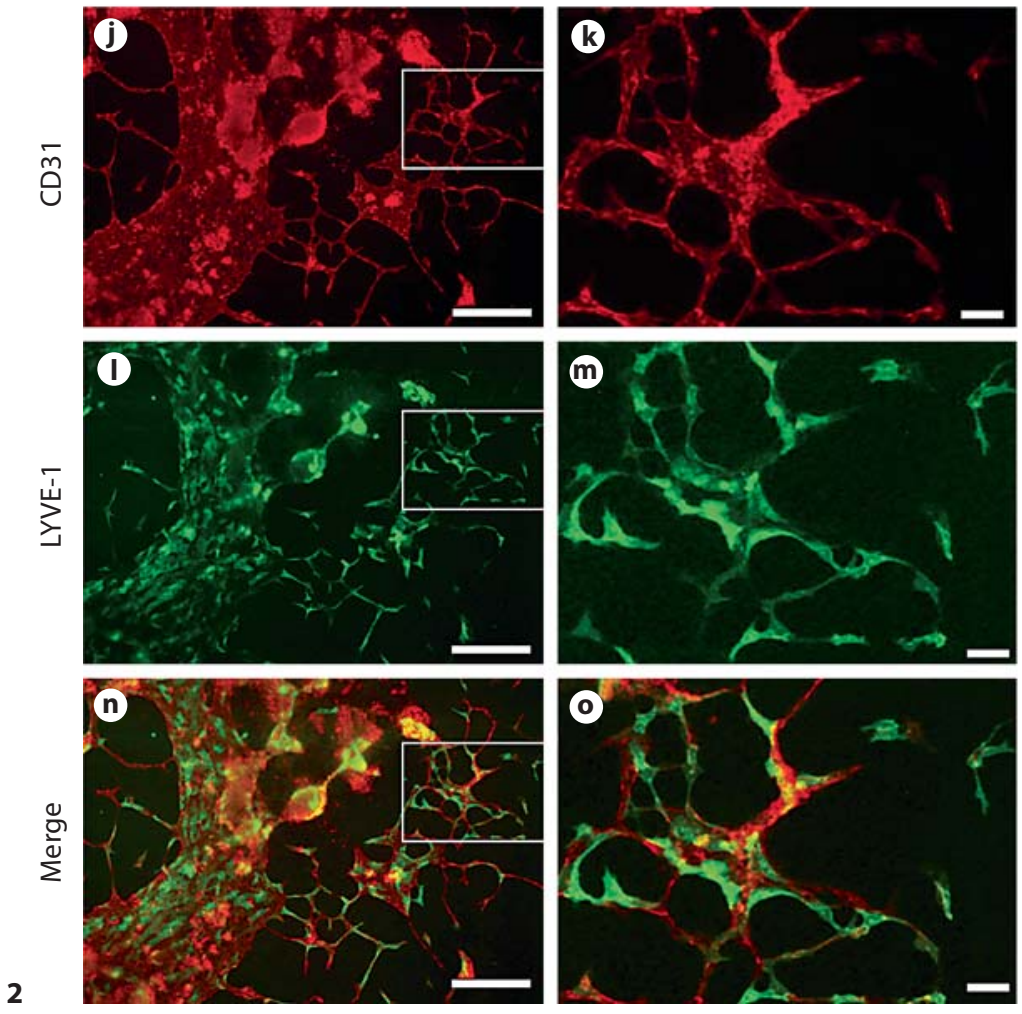

$\mathbf{p}$
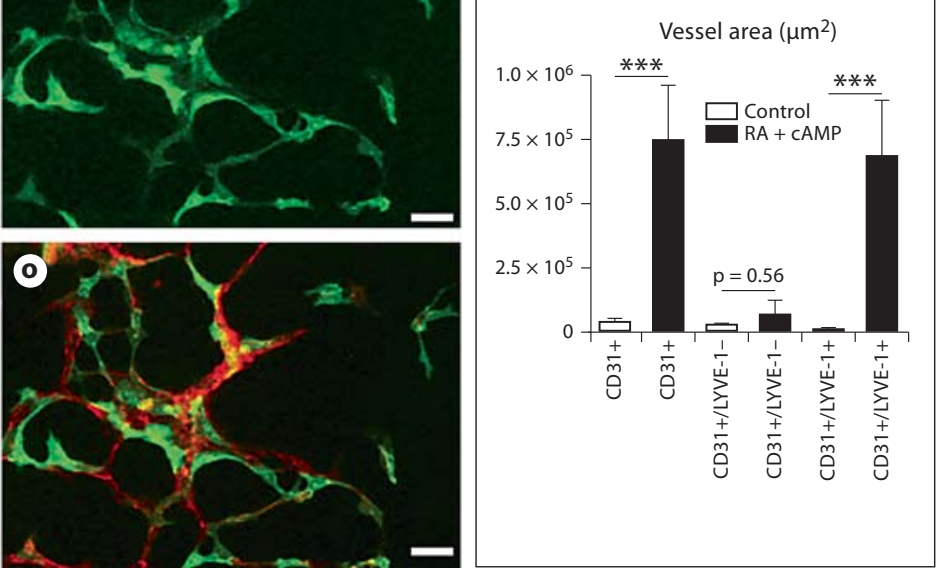


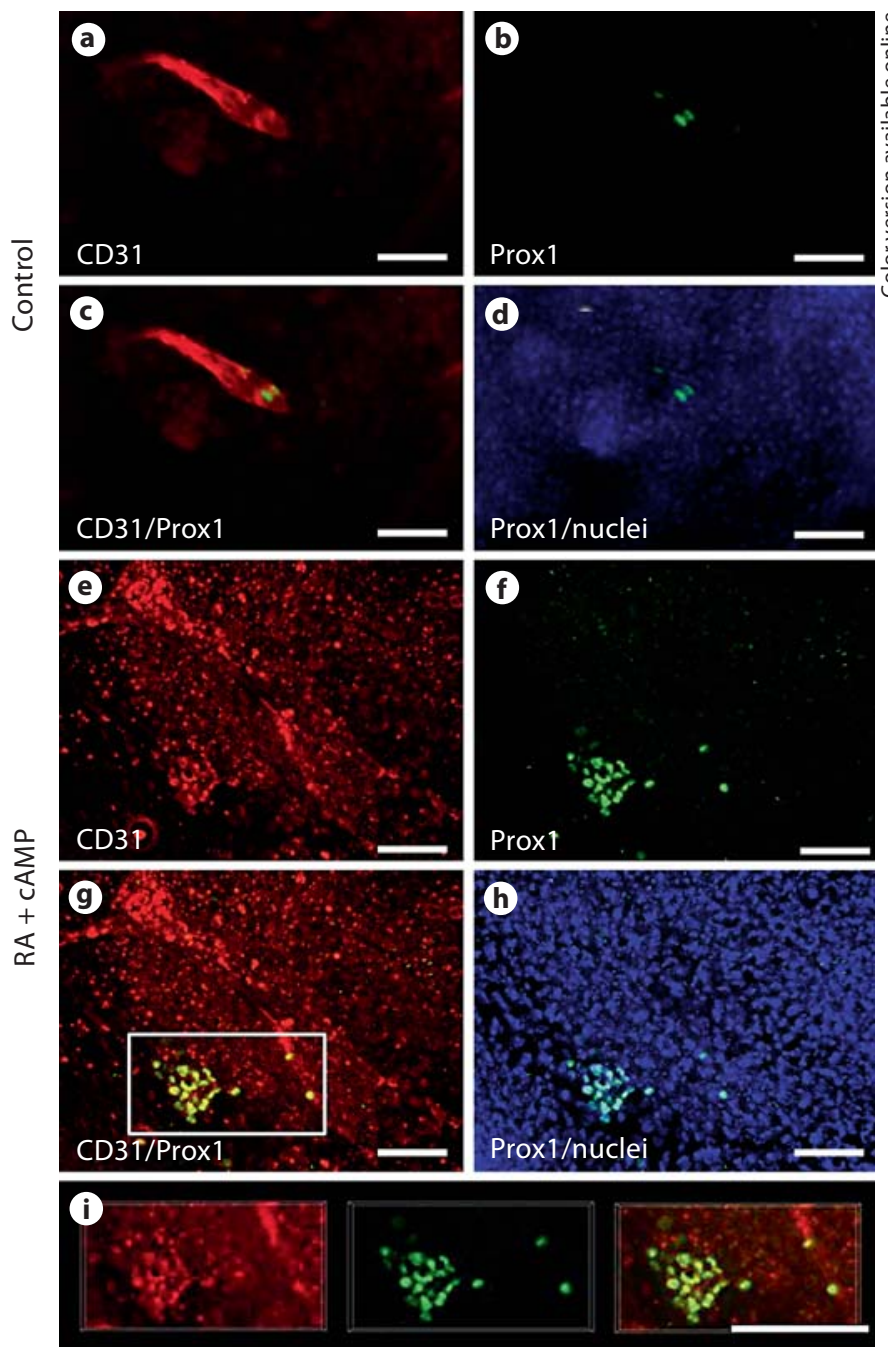

Fig. 3. Incubation of EBs with RA and cAMP increases formation of Prox1+/LYVE-1+/CD31+ cell clusters. Double immunofluorescence analysis revealed that incubation with RA and cAMP induced expression of Proxl (cell nucleus staining; f, $\mathbf{g}, \mathbf{h}, \mathbf{i}$ ) in CD31+ (cell membrane staining; e, g, i) and in LYVE-1+ (online suppl. fig. 1E-H) endothelial cell clusters, compared with control EBs where only a few Prox $1+(\mathbf{b}-\mathbf{d})$ and $\operatorname{CD} 31+(\mathbf{a}, \mathbf{c})$ cells were

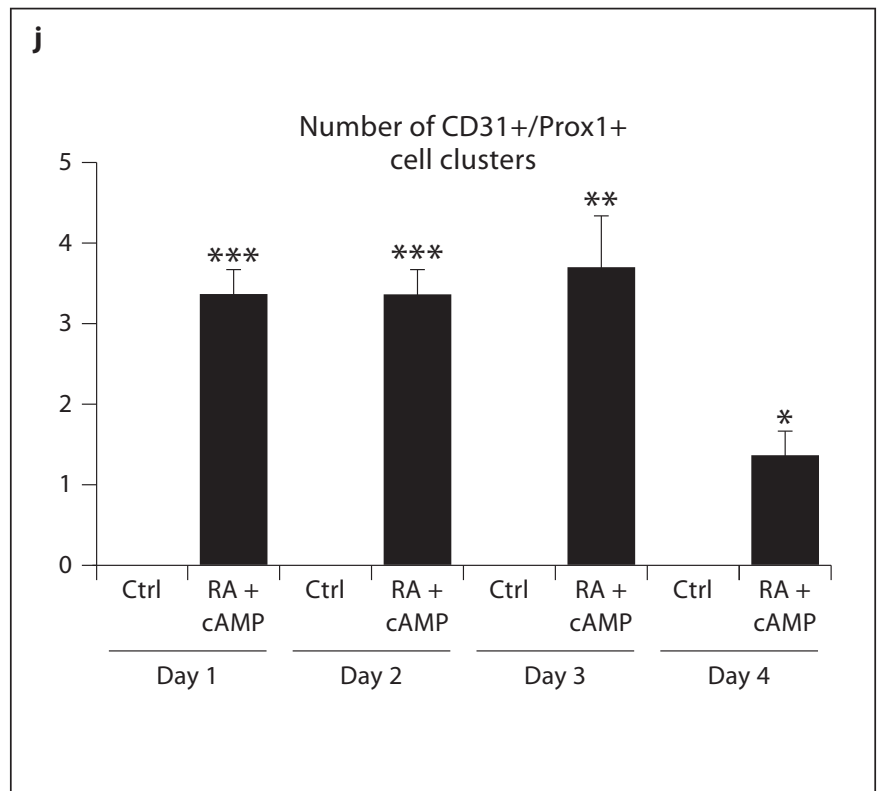

visible. Cell nuclei are visible in $\mathbf{d}$ and $\mathbf{h}$. Pictures were obtained after 2 days of exposure to RA and cAMP. Quantitative analysis revealed that daily treatment with RA and cAMP increased the number of CD31+/Prox1+ cell clusters in EBs compared with negative controls, beginning at 1 day after treatment initiation $(\mathbf{j})$. Data are expressed as mean values + SEM $(n=5)$. Scale bars $=50$ $\mu \mathrm{m} .{ }^{*} \mathrm{p}<0.05{ }^{* *} \mathrm{p}<0.01{ }^{* * *} \mathrm{p}<0.001$.
We next investigated whether the effects of RA and cAMP on the formation of lymphatic vessel-like structures were inhibited by the RAR- $\alpha$-specific antagonist Ro 41-5253. Incubation of EBs with Ro 41-5253 alone did not affect the formation of CD31+/LYVE-1+ or CD31+/ LYVE-1+/Prox1+ structures, whereas Ro 41-5253 potently inhibited the induction of lymphatic vessel-like structures by RA and cAMP (fig. 1c; table 1). The cAMP-de- pendent PKA inhibitor $\mathrm{H} 89$ also completely blocked the induction of CD31+/LYVE-1+/Prox1+ structures by RA and cAMP; incubation of EBs with $\mathrm{H} 89$ alone had no effects (fig. 1c; table 1). Together, these findings indicate a sufficient role of the RAR- $\alpha$ and cAMP-PKA pathway in promoting the retinoid effects on lymphatic differentiation in the mouse EB assay. 
In vivo Effects of $R A$ in Developing Mouse Embryos

We investigated whether RA could affect in vivo development of the mouse lymphatic vascular system. Immunohistochemical analyses were used to determine whether RA receptors are expressed by endothelial cells of the cardinal vein of mouse embryos at ED 9.5-11.5, when expression of LYVE-1 and Prox1 is first observed. We found that RAR- $\alpha$ was expressed (fig. $4 \mathrm{~d}$, arrowheads) by the endothelial cells of the LYVE-1+ cardinal vein (fig. 4c, arrowheads) and by the developing lymph sacs at ED 11.5. In fact, RAR- $\alpha$ was expressed on/nearby the cardinal veins by ED 10.5 (fig. 4e) and 9.5 (fig. 4f), time points at which the jugular lymph sacs had not yet formed.

Based on the observed expression pattern of RAR- $\alpha$ during lymphatic development, we investigated whether RA also induced in vivo expression of LYVE-1 and Prox1. To this end, we injected RA intraperitoneally into pregnant mice, to expose the developing embryos to an in utero excess of RA. RA ( $25 \mathrm{mg} / \mathrm{kg}$ of weight) was injected on days 8 and 10 of pregnancy. ED 8 was chosen as the first injection time point to ensure RA exposure before LYVE-1 and Prox 1 were expressed by cardinal vein endothelium (at ED 9). ED10 was chosen for the second injection to ensure that lymphatic-committed endothelial cells were exposed to excess RA as they were budding from the cardinal veins.

At ED 11.5, when the first jugular lymph sacs are visible, immunohistochemistry with a short 1-min colorimetric reaction revealed strong LYVE-1 expression on the cardinal vein endothelial cells of embryos that were exposed to RA in utero (fig. 5d-f) but not of control embryos (fig. $5 \mathrm{a}-\mathrm{c}$ ). A quantitative analysis confirmed that LYVE-1 expression was significantly upregulated upon treatment (fig. $5 \mathrm{j}$ ). We also observed an increase in the size of the primary jugular lymph sacs in embryos exposed to RA (fig. 5k; $\mathrm{p}=0.19$ ). In contrast, in utero exposure of the embryos to Ro 41-5253, an inhibitor of RAR- $\alpha$, led to a decrease in LYVE-1 expression by the ECs of the cardinal vein and of the jugular lymph sac (fig. $5 \mathrm{~g}-\mathrm{j}$ ), as compared to control embryos (fig. 5a-c, j). The lymph sac area was not affected by Ro 41-5253 (fig. 5k). Importantly, differential immunofluorescence analyses of CD31 and Prox1 expression revealed that embryonic exposure to RA increased the number of Prox1+ endothelial cells in the cardinal veins and of sprouting Prox $1+$ cells that form the lymph sacs (fig. 6g-1), compared with control embryos (fig. 6a-f). A quantitative analysis confirmed that the number of CD31+/Prox1+ cells in the jugular area of the embryos significantly increased upon RA treatment
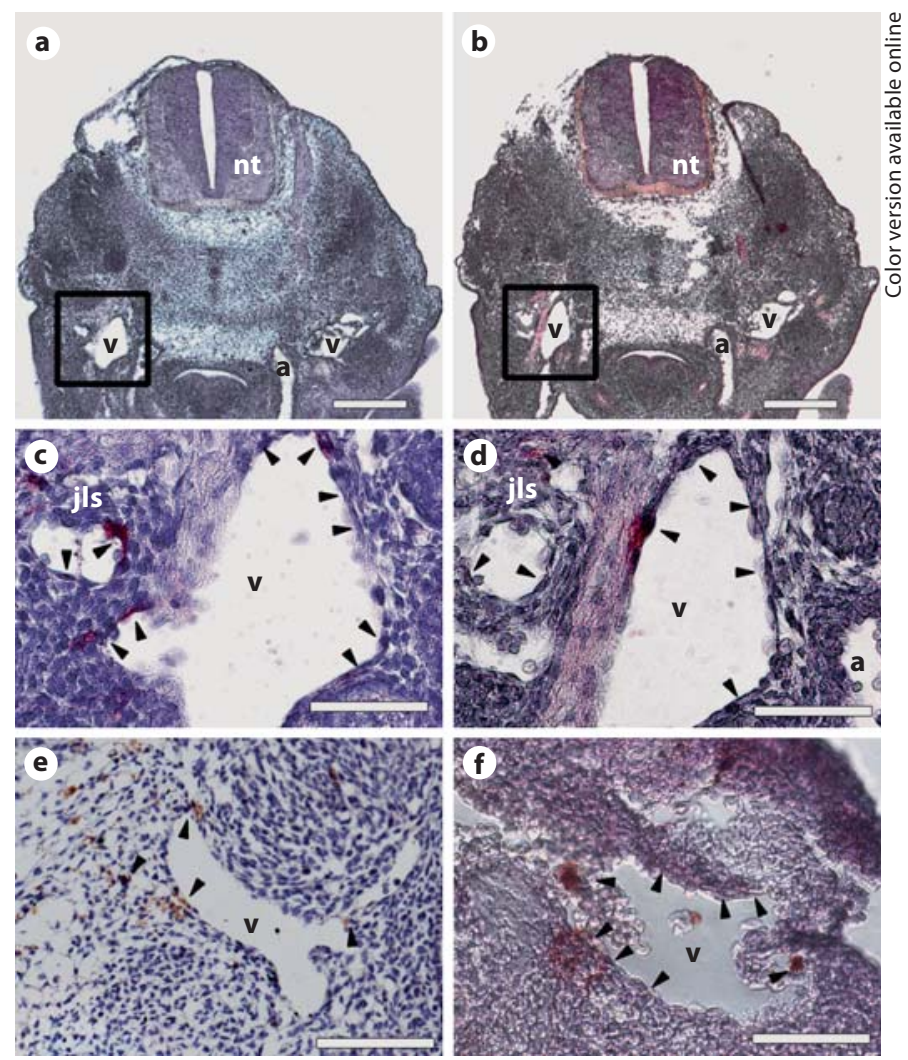

Fig. 4. RAR- $\alpha$ is expressed by endothelial cells of the cardinal veins of mouse embryos. Immunohistochemical analysis of mouse embryos for LYVE-1 (a, c: ED 11.5) and RAR- $\alpha$ (b, d: ED 11.5; e: ED 10.5; f: ED 9.5) revealed that RAR- $\alpha$ (b, d, arrowheads) is expressed by/near the endothelial cells of the LYVE-1+ (a, c, arrowheads) cardinal veins and forming jugular lymph sacs of ED 11.5 as well as in/near the cardinal veins of ED 10.5 (e, arrowheads) and ED 9.5 (f, arrowheads) mouse embryos. Two serial sections are shown in $\mathbf{a}$ and $\mathbf{b} . \mathbf{a}, \mathbf{b}$ Scale bars $=50 \mu \mathrm{m} ; \mathbf{c}-\mathbf{f}$ scale bars $=20 \mu \mathrm{m}$. Cell nuclei were counterstained with hematoxylin. $\mathrm{a}=$ Dorsal aorta; $\mathrm{jls}=$ jugular lymph sac; $\mathrm{nt}=$ neural tube; $\mathrm{v}=$ cardinal vein.

(fig. 6r), whereas injection of Ro 41-5253 slightly decreased the number of CD31+/Prox $1+$ cells (fig. $5 \mathrm{~m}-\mathrm{r}$ ) as compared to controls (fig. 6a-f, r). The increase in CD31+/ Prox $1+$ cells in the cardinal veins was not due to enhanced cell proliferation, as revealed by the results of phosphohistone 3 stains (data not shown). ED $11.5 \mathrm{em}-$ bryos, at gross examination, showed a slight increase in blood presence in the extra-embryonic tissues, a lower amount of blood in the heart region as well as a lower heartbeat frequency (data not shown). The treatment also caused a mild reduction of the caudal length as previously shown [37] (data not shown). 

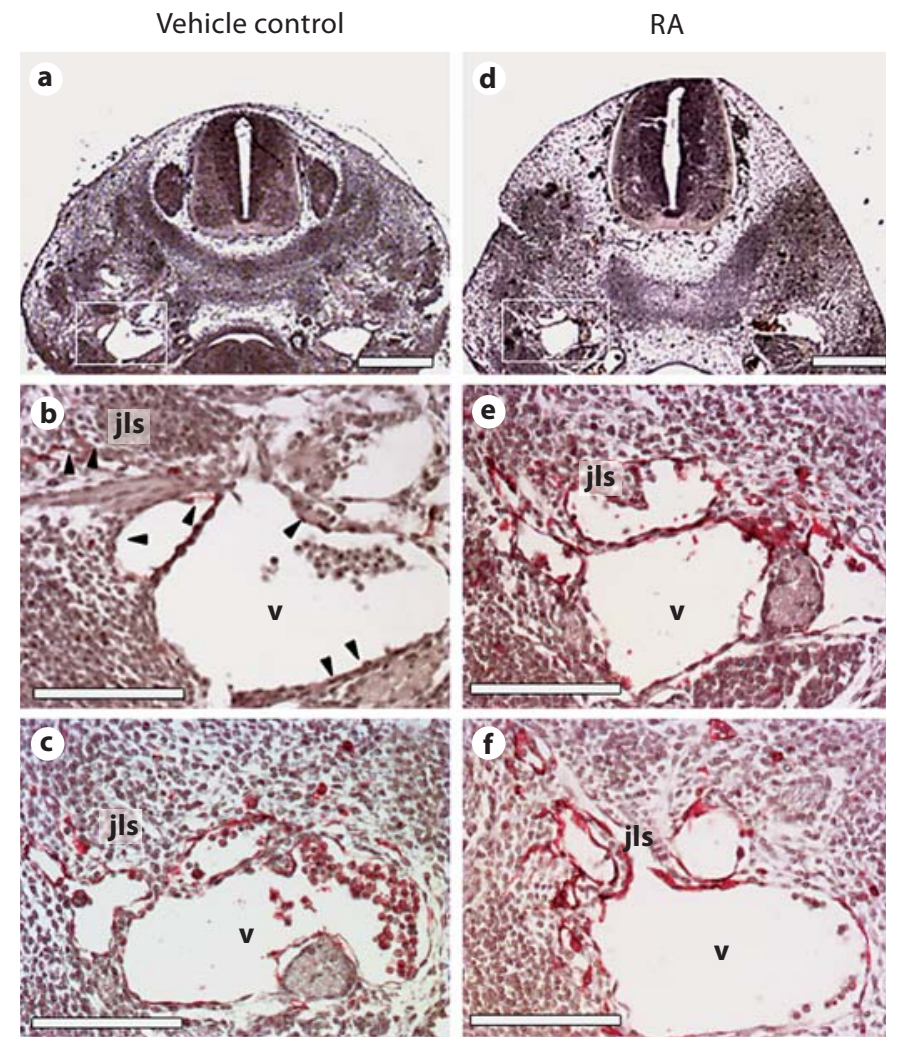

Fig. 5. In utero exposure of mouse embryos to excess of RA upregulates endothelial LYVE-1 expression in the anterior cardinal veins and jugular lymph sacs. Immunohistochemical analysis of paraffin sections from ED 11.5 mouse embryos for LYVE-1 revealed that the endothelial cells of the anterior cardinal veins and of the forming lymph sacs up-regulated the expression of LYVE-1 after in utero exposure to an excess of RA (d-f and $\mathbf{j})$, as compared with control embryos (a, b, arrowheads, $\mathbf{c}$ and $\mathbf{j})$. Treatment with
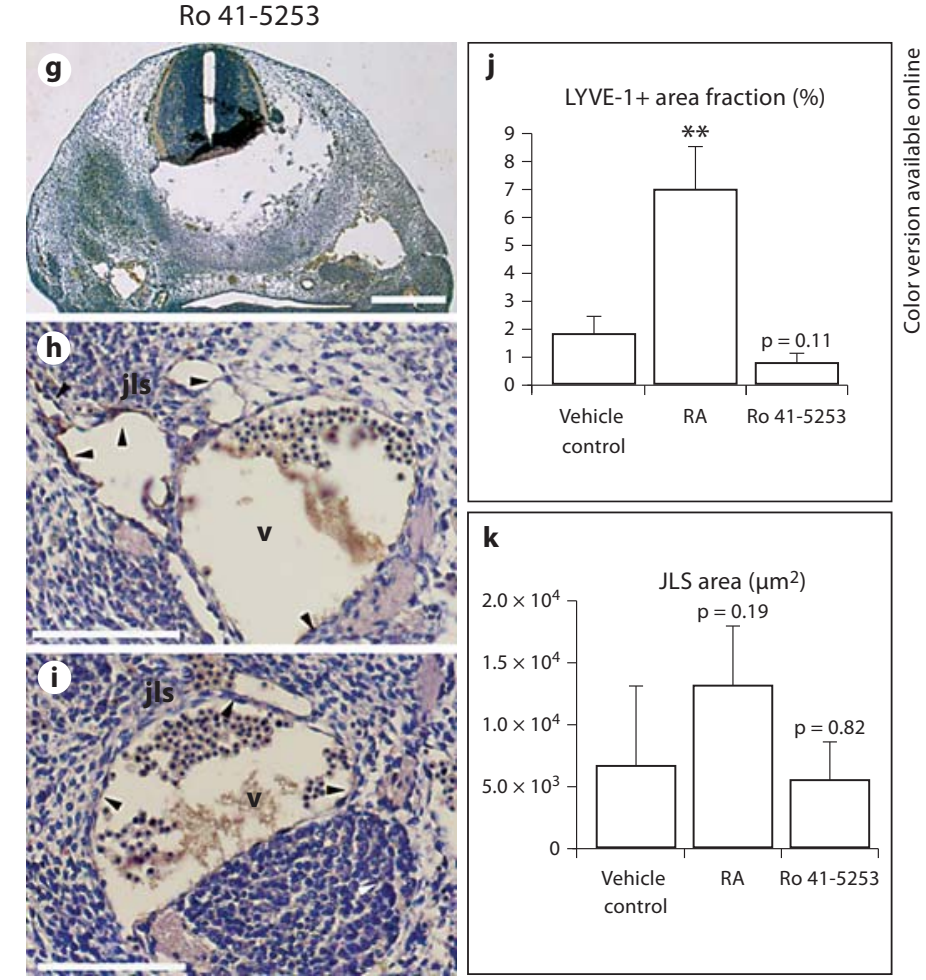

the RAR- $\alpha$ antagonist Ro 41-5253 decreased LYVE-1 expression (g-j). The jugular lymph sac area was enlarged after RA treatment as compared to controls $(\mathbf{k}) . \mathbf{b}, \mathbf{c}, \mathbf{e}, \mathbf{f}, \mathbf{h}$ and $\mathbf{i}$ are sections of embryos from two independent pregnant mice each. a, d, $\mathbf{g}$ Scale bars $=100 \mu \mathrm{m} ; \mathbf{b}, \mathbf{e}, \mathbf{h}, \mathbf{c}, \mathbf{f}, \mathbf{i}$ scale bars $=50 \mu \mathrm{m}$. jls $=$ Jugular lymph sac; $\mathrm{nt}=$ neural tube; $\mathrm{v}=$ cardinal vein. Data are expressed as mean values $+\mathrm{SD}(\mathrm{n}=4) .{ }^{* *} \mathrm{p}<0.01$.

Table 1. Blockade of RAR- $\alpha$ or of PKA inhibits the induction of Proxl+cell clusters by RA and cAMP

\begin{tabular}{|c|c|c|c|c|}
\hline & \multicolumn{2}{|c|}{ Day 16} & \multicolumn{2}{|c|}{ Day 18} \\
\hline & $\mathrm{EBs}^{1}$ & clusters $^{2}$ & $\mathrm{EBs}^{1}$ & clusters $^{2}$ \\
\hline Control & $0 / 9$ & 0 & $0 / 9$ & 0 \\
\hline $10 \mu \mathrm{M}$ RA & $0 / 9$ & 0 & $0 / 9$ & 0 \\
\hline $10 \mu \mathrm{M}$ RA + $0.5 \mathrm{mM}$ cAMP & $9 / 9$ & $3+1$ & $9 / 9$ & $1+0$ \\
\hline $10 \mu \mathrm{M} R A+0.5 \mathrm{mM}$ cAMP $+10 \mu \mathrm{M}$ Ro $41-5253$ & $0 / 9$ & 0 & $0 / 9$ & 0 \\
\hline $10 \mu \mathrm{M} R A+0.5 \mathrm{mM}$ cAMP $+10 \mu \mathrm{M} \mathrm{H} 89$ & $0 / 9$ & 0 & $0 / 9$ & 0 \\
\hline $0.5 \mathrm{mM}$ cAMP & $0 / 9$ & 0 & $0 / 9$ & 0 \\
\hline $10 \mu \mathrm{M}$ Ro $41-5253$ & $0 / 9$ & 0 & $0 / 9$ & 0 \\
\hline $10 \mu \mathrm{M}$ H89 & $0 / 9$ & 0 & $0 / 9$ & 0 \\
\hline
\end{tabular}

Four days of treatment with RA and cAMP induced the formation of 3+1 Prox1+/LYVE-1+/CD31+ cell clusters per EB. These clusters were found in 9 of 9 EBs analyzed. Ro 41-5253 (RAR- $\alpha$ inhibitor) and H89 (PKA inhibitor) completely prevented the induction of Prox1 endothelial cell clusters by RA and cAMP. No induction was seen after incubation with RA alone, cAMP alone or with the inhibitors alone.

${ }^{1}$ Number of analyzed EBs. ${ }^{2}$ Average number of CD31+/LYVE$1+/$ Prox $1+$ cell clusters per EB + SD . 
Fig. 6. In utero exposure of mouse embryos to excess of RA increases the number of Prox1-positive lymphatic progenitor cells in the cardinal veins and jugular lymph sac forming areas. Double-immunofluorescence analysis of ED 11.5 mouse embryos exposed to excess RA (g-I) or vehicle (a-f) for CD31 (cell membrane staining) and Prox1 (cell nucleus staining) revealed that RA exposure increased the number of Prox1+ endothelial cells in the anterior cardinal veins and in the area of the jugular lymph sacs as compared with control (r). Ro 41-5253 treatment (m-q) slightly reduced the number of Prox $1+/ C D 31+$ cells in the jugular area as compared with control (r). $\mathbf{d}-\mathbf{f}, \mathbf{j}-\mathbf{I}$ and $\mathbf{p}$, q show representative sections of embryos from independent vehicle control, RA- or Ro 41-5253-treated pregnant mice, respectively. Cell nuclei are shown in $\mathbf{b}, \mathbf{h}, \mathbf{n} . \mathbf{a}, \mathbf{b}, \mathbf{g}, \mathbf{h}, \mathbf{m}, \mathbf{n}$ Scale bars $=100 \mu \mathrm{m} ; \mathbf{c}-\mathbf{f}, \mathbf{i}-\mathbf{I}, \mathbf{o}-\mathbf{q}$ scale bars $=50$ $\mu \mathrm{m} . \mathrm{a}=$ Dorsal aorta; jls = jugular lymph sac; $\mathrm{nt}=$ neural tube; $\mathrm{v}=$ cardinal vein. Data are expressed as mean values $+\mathrm{SD}$ $(\mathrm{n}=4) .{ }^{* * *} \mathrm{p}<0.001$.
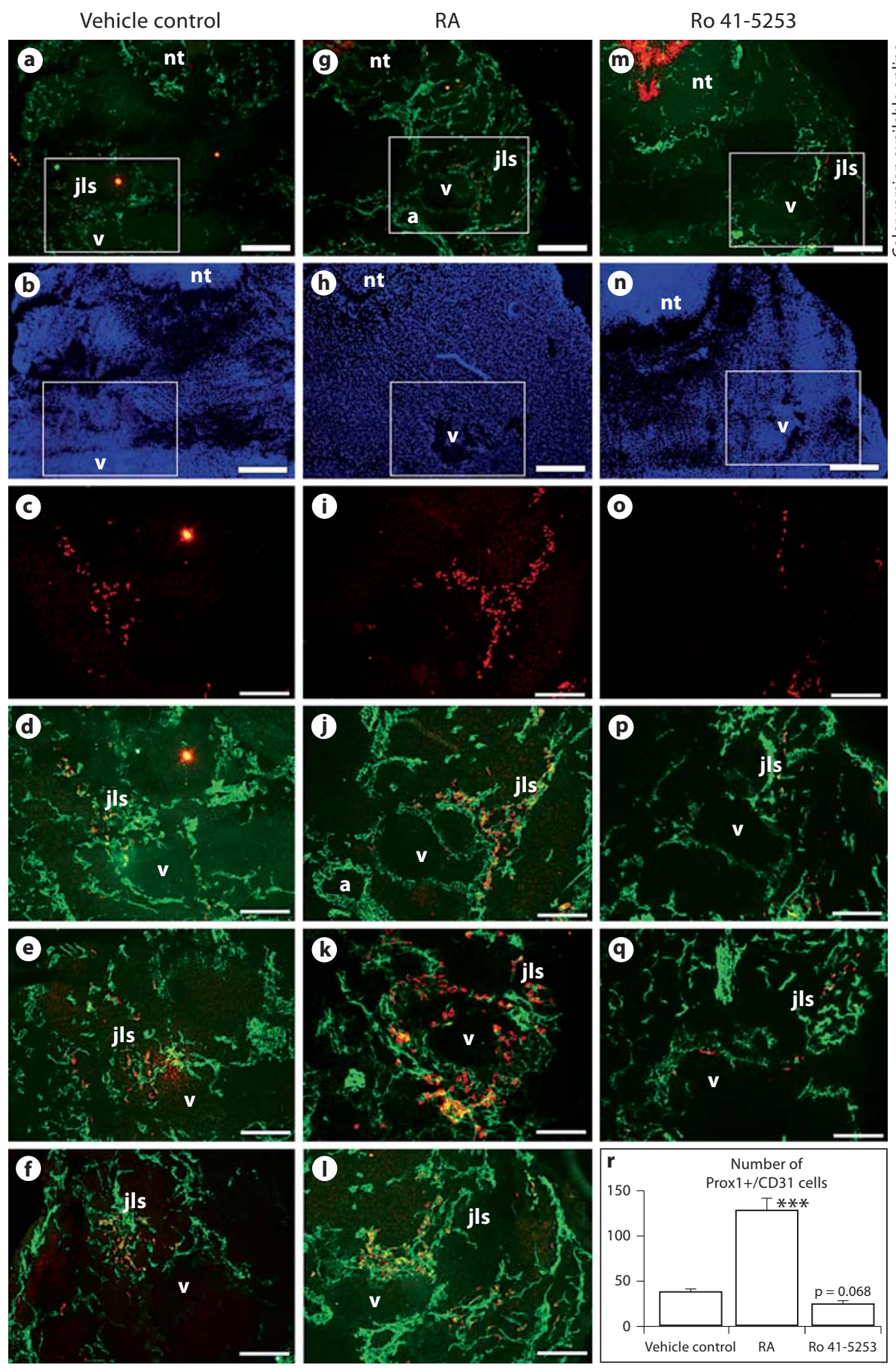

RA Upregulates Expression of LYVE-1 and VEGFR-3 in the Vasculature of $\mathrm{X}$. laevis Embryos

Due to their small size, transparency and easy maintenance, $X$. laevis embryos are a useful animal model for studying development [38], particularly that of the lymphatic vasculature $[39,40]$. Xenopus embryos were incu- bated with RA and cAMP from stage 28, when the Prox1 expression is first detected on the vasculature, until stage 39 , when lymphatic endothelial cells start to sprout from the lymph heart and the cardinal vein to form the first lymphatic vessels. In situ hybridization analyses revealed that exposure of the embryos to RA increased expression 

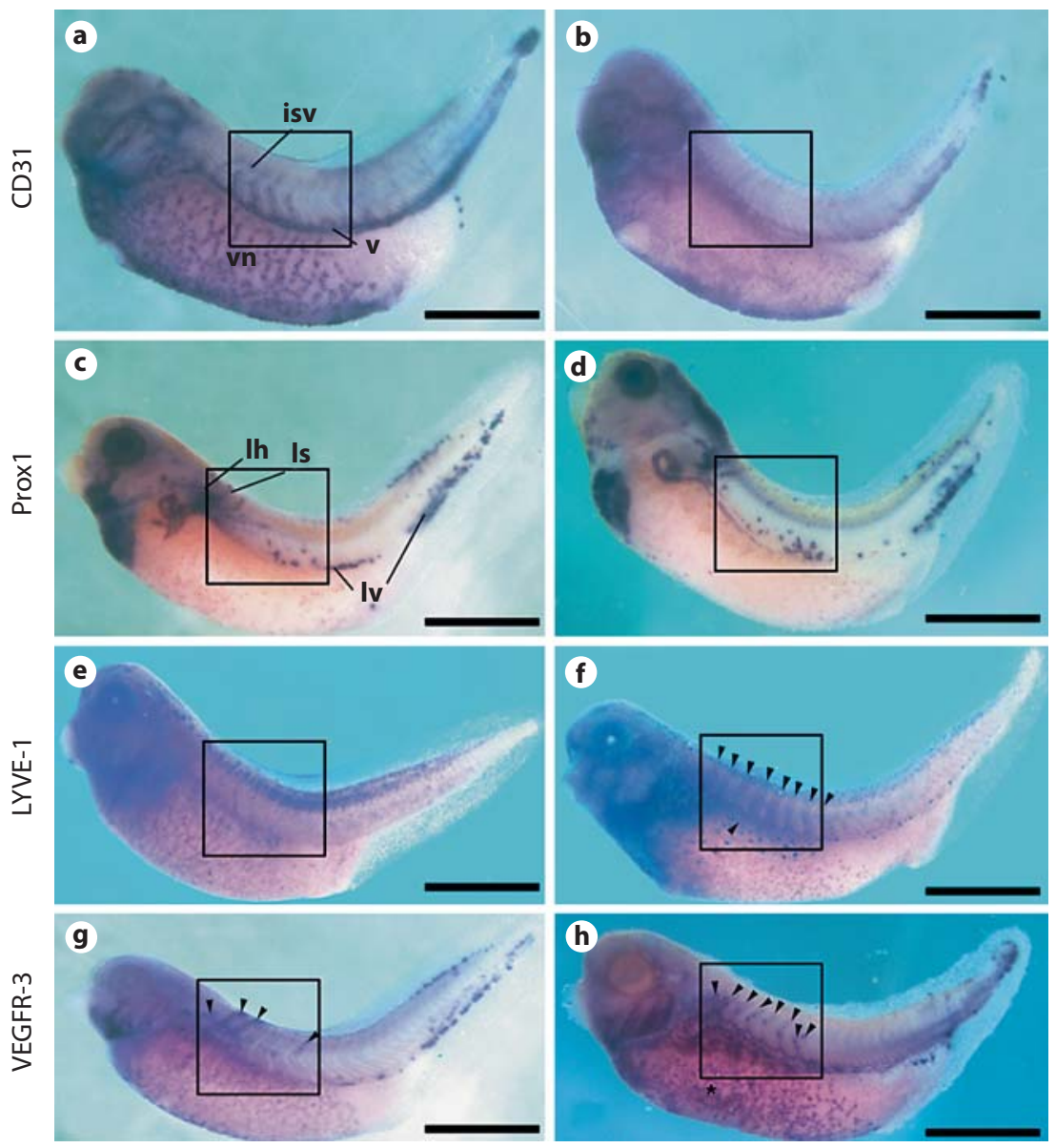

Fig. 7. Incubation of $X$. laevis embryos with excess of RA downregulates CD31 and upregulates the lymphatic markers LYVE-1 and VEGFR-3 in the developing vasculature. X. laevis tadpoles were bathed in RA in combination with cAMP (b, d, f, $\mathbf{h}, \mathbf{j}, \mathbf{I}, \mathbf{n}, \mathbf{p})$ or in DMSO (a, $\mathbf{c}, \mathbf{e}, \mathbf{g}, \mathbf{i}, \mathbf{k}, \mathbf{m}, \mathbf{0})$ from embryonic stages 28 to 39. In situ hybridization for CD31 (a, b, i, j), Prox1 (c, d, k, I), LYVE-1 (e, f, m, n) or VEGFR-3 $(\mathbf{g}, \mathbf{h}, \mathbf{o}, \mathbf{p})$ revealed that RA and cAMP reduced CD31 expression $(\mathbf{b}, \mathbf{j})$ in the developing vasculature, including intersomitic veins (isv), the cardinal vein (v) and the vitelline network (vn), compared with controls (a, i). No effects on Prox1 expression and/or distribution in the lymph heart (lh), lymphatic sprouts (ls) or in the lymphatic endothelial cells of venous origin (lv) were observed (c, d, k, I). In contrast, LYVE-1 expression was upregulated in the intersomitic veins and in the cardinal vein (f, arrowheads, $\mathbf{n}$ ) compared with controls (e, $\mathbf{m})$. RA incubation also upregulated VEGFR-3 expression in the cardinal vein and vitelline network (h, arrowheads and asterisk, respectively, $\mathbf{p}$ ) compared with control embryos (g, arrowheads, $\mathbf{o}$ ). Scale bars $=50 \mu \mathrm{m} ; \mathbf{i}-\mathbf{p}$ scale bars $=5 \mu \mathrm{m}$. q Quantitative analysis of the number of VEGFR-3+ sprouts from the anterior cardinal vein following exposure to DMSO (vehicle) or the combination of RA and cAMP. Data are expressed as means + SEM ( $n=150$ per treatment group).
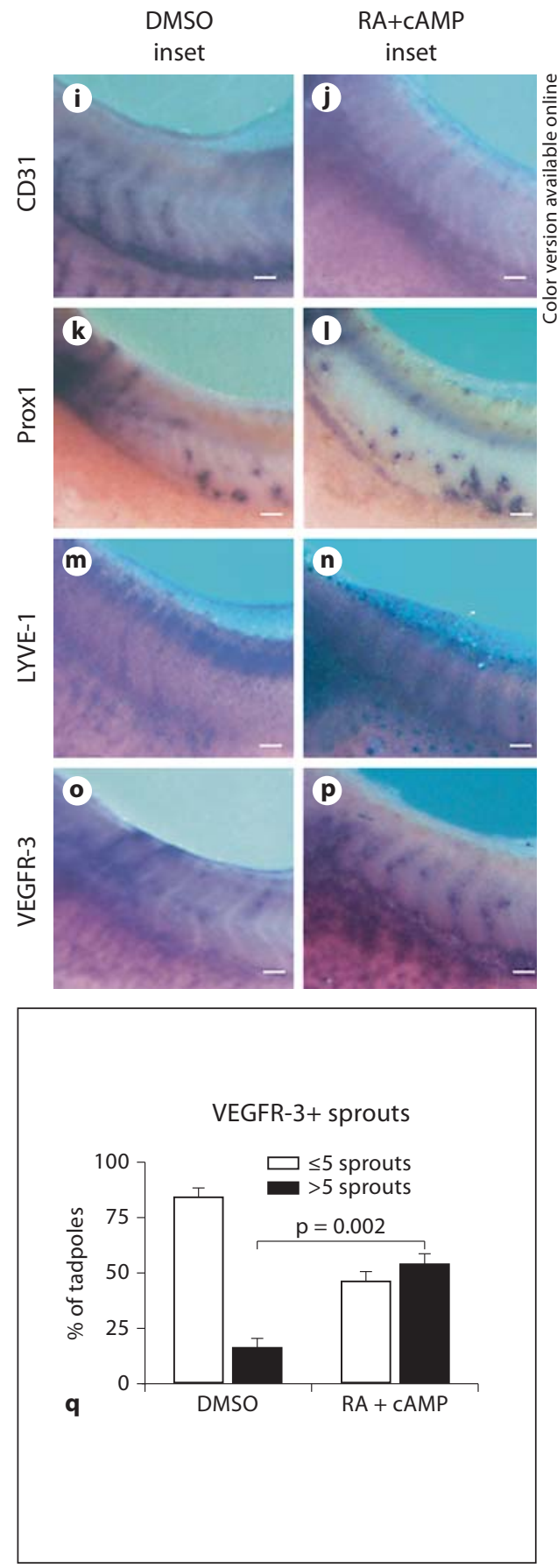
of VEGFR-3 (fig. 7g, h, o, p) and LYVE-1 (fig. 7e, f, m, n) throughout the developing vasculature, including the intersomitic veins (fig. $7 \mathrm{f}, \mathrm{h}, \mathrm{n}, \mathrm{p}$, arrowheads), the cardinal vein (fig. $7 f, h, n, p$, arrows) and the vitelline network (fig. 7h, asterisks), indicative of enhanced lymphatic competence. Expression of CD31 was downregulated throughout the entire vasculature (fig. $7 \mathrm{a}, \mathrm{b}, \mathrm{i}, \mathrm{j}$ ); this was an important observation because CD31 expression is reduced on lymphatic vessels, compared to blood vessels, during normal development. Prox $1+$ cells were found in the anterior and posterior cardinal veins, the tip of the tail, the lymph heart and the first sprouts from the lymph heart in both the RA-exposed and control embryos (fig. 7c, d, k, l). A quantitative analysis of the VEGFR-3 expression revealed a significant increase in the number of VEGFR-3+ sprouts that developed from the anterior cardinal vein and the lymph heart following exposure to the combination of RA and cAMP, compared with controls $(\mathrm{p}=0.002$; fig. $7 q$ ). Only $16+5 \%$ of the control embryos had $>5$ VEGFR-3+ sprouts, compared to $54+5 \%$ of RA-exposed embryos. Moreover, in the embryos exposed to RA, VEGFR-3+ sprouts were longer than those of the control group (fig. 7g, h, o, p).

\section{Discussion}

This is the first demonstration that all-trans-RA is likely involved in the earliest steps of lymphatic vascular development, namely the acquisition of lymphatic competence and commitment by endothelial cells of the embryonic cardinal vein; RA appears to do so by upregulating the lymphatic markers LYVE-1 and Prox1.

Our studies with the mouse EB vascular differentiation assay found that VEGF-C, growth hormone, IGF-1 and IL-7 increased the area of CD31+/LYVE-1+ vessellike structures in the EB assay; these findings are in agreement with the reported lymphangiogenic activity of growth hormone [41] and IGF-1 [42] as well as the lymphatic reprogramming activity of IL-7 in cultured endothelial cells [43]. Most interestingly, however, we found that RA, alone and combination with cAMP, potently upregulated LYVE-1 expression in CD31+ vascular structures. The LYVE-1+, lymphatically competent endothelial cells emerged from the pre-existing CD31+ blood vascular endothelium, supporting the centrifugal theory of lymphatic vasculature development from pre-existing embryonic veins originally proposed by Sabin [44] in 1902. However, the combination of RA and cAMP also induced the formation of rare CD31+/LYVE-1+/Prox1+ cell clusters, independently from the CD31+ vessel-like networks. These findings indicate that mesenchymal progenitor cells might differentiate directly into lymphatically competent endothelial cells; this is in agreement with the centripetal theory of mesenchyme-derived lymphatic progenitors proposed by Huntington and McClure [45] in 1910. The mouse EB vascular differentiation assay represents a suitable model for lymphatic vasculature development in vivo, since lymphatic vessels in mice appear to be predominantly derived from pre-existing embryonic veins, as suggested by recent lineage-tracing studies [46], although there might be a contribution by mesenchyme-derived progenitor cells $[47,48]$. EB cells appear to be more responsive to the induction of lymphatic commitment than differentiated endothelial cells, since there was no induction of Prox 1 by RA and cAMP in cultured HUVECs (online suppl. fig. S2C). In the same way, RA and cAMP treatment of cultured human umbilical vein endothelial cells did not induce the expression of Sox18 (data not shown). The absence of Proxl and Sox18 induction in human umbilical vein endothelial cells, in a two-dimensional culture system, might indicate the need for additional inducing factors derived from the microenvironment that are present in the EBs.

RA binds to nuclear RARs, which after forming heterodimers with retinoid $\mathrm{X}$ receptors, activate histone acetylation and gene transcription. Our finding that Ro 415253 inhibited the induction of lymphatic vascular structures by RA indicated that the RA effect was mediated via RAR- $\alpha$. Ro 41-5253 antagonizes the transactivation of RARs by RA, with a high affinity for RAR- $\alpha$; 50 - to 100 fold higher concentrations of Ro 41-5253 are required to reduce the activation of RAR- $\beta$ and 1,000-fold higher concentrations are required to inhibit RAR- $\gamma$ [49]. The potentiation of RA's effects by cAMP and the inhibition by H89, a cAMP-dependent PKA inhibitor, indicate that the effects of RA are mediated by a pathway that includes CAMP and PKA [50], although we cannot completely exclude that $\mathrm{H} 89$, at the dose of $10 \mu \mathrm{M}$ used, might also have exerted some off-target effects, even though $\mathrm{H} 89$ alone had no detectable effects. Indeed, it has been found that RA and cAMP have synergistic effects in several differentiation processes including neural [36], smooth muscle [35] and endothelial progenitor cell [34] differentiation, although the precise mechanisms of RA and cAMP interaction remain to be established. This concept is supported by our in silico analyses; the AliBaba (http://www.gene-regulation.com/pub/programs.html), PROMO (http://alggen. lsi.upc.es/cgi-bin/promo_v3/promo/promoinit.cgi? dirDB=TF_8.3) and TESS (http://www.cbil.upenn.edu/ 
cgi-bin/tess/tess) software indicate that retinoid X receptors and RARs, as well as cAMP response element-binding proteins, bind to the promoter regions of the mouse LYVE1 and Proxl genes (data not shown).

The role of retinoid signaling in the mediation of lymphatic competence is supported by immunohistochemical analyses showing that RAR- $\alpha$ is strongly expressed by the endothelial cells of the embryonic cardinal veins at ED 9.5, when lymphatic competence and commitment are first detected and at EDs 10.5 and 11.5, when LEC progenitors bud off from the cardinal vein $[8,11]$. The finding that at EDs 9.5 and 10.5, RAR- $\alpha$ was also expressed by some cells in clusters near cardinal veins raises the possibility that surrounding cells might contribute, by indirect effects, to the induction of lymphatic competence by RA. However, our observation that incubation of human umbilical vein endothelial cells with RA increased LYVE-1 mRNA expression by $>2$-fold ( $p=0.042$; online suppl. fig. S2A) and also increased LYVE-1 protein levels (online suppl. fig. S2B, C), suggests that the effects of RA are directly mediated by endothelial cells.

To investigate whether RA also promotes lymphatic competence and commitment in vivo, we used established models of Xenopus and mouse lymphatic development. Previous studies have shown that excess or lack of RA during early embryogenesis causes malformations $[51,52]$, through mispatterning of the embryonic tissue layers and the anterior-posterior body axis. Several RAR knockout mice have been created [53]. Together, RAR deficiency and vitamin A deprivation lead to a plethora of embryonic defects, including those of the eye, respiratory tract, heart, kidney, genital tract, bones and limbs, as well as axial skeletal and neural malformations [26]. Importantly, however, vitamin A deficiency is also associated with cardiovascular problems and enlargement of the anterior cardinal veins in rat embryos $[27,28]$. Zebrafish that express mutant forms of the RA-metabolizing enzyme Cyp26A1 also display patterning defects in multiple organs, including the common cardinal vein, pectoral fin, tail, hindbrain and spinal cord. Because of the multitude of developmental defects caused by RA deficiency or exposure [54-58], we investigated the in vivo effects of RA exposure over only short time periods and during the earliest phases of lymphatic development.

Importantly in mice, increased levels of RA in utero upregulated LYVE-1 expression in the endothelial cells of the anterior part of the cardinal veins and of the forming lymph sacs (which also slightly increased in size). An increased number of CD31+/Prox1+ endothelial cells was detected in the cardinal veins and the developing lymph sacs. In contrast, in utero injection of Ro 41-5253, a specific inhibitor of RAR- $\alpha$ signaling [49], reduced LYVE-1 expression and decreased the number of CD31+/Prox1+ cells in the jugular area of the ED 11.5 embryos. However, the extent of inhibition was rather mild and the quantitative evaluation did not reach a significance level of 0.05 , in part due to the rather high variability among the different embryos. Other possible explanations for these findings are (1) a potential compensatory role of RAR- $\beta$ and/or RAR- $\gamma$ [59]; (2) noncanonical activity of RA via CREB or ERK [60], and (3) an incomplete blockade of RAR- $\alpha$ activity by the two injections of Ro 41-5253.

Exposure of stage 28-39 Xenopus embryos to RA downregulated CD31 expression but enhanced expression of VEGFR-3 and LYVE-1 in the developing vasculature, mainly in the intersomitic veins, the cardinal vein and the vitelline vein network. Because incubation of Xenopus embryos with different concentrations of Ro 415253 induced lethality of stage 28 tadpoles (data not shown), the vascular effects of specific blockade of RAR$\alpha$ could not be evaluated in the Xenopus model. In addition, morpholino knockdown experiments would not represent a suitable loss-of-function approach since it has been shown that knockdown of either RAR- $\alpha 1$ or RAR$\alpha 2$ (or both) leads to a severe phenotype in Xenopus embryos, mainly regarding the head formation, already at the early stage 20 (the first Prox 1 expression in Xenopus is at stage 28) [61].

All-trans-RA and its derivatives exert many different and often contradictory effects on cells, depending on context, cell type and other variables; its role in angiogenesis, for example, remains controversial so far. It is has been found that RA induces in vitro tube formation of HUVECs [62] via a possible paracrine effect by inducing endogenous VEGFA and fibroblast growth factor-2 production as well as angiogenesis in bovine aortic endothelial cells in vitro [63]. On the other hand, RA caused endothelial cells to become refractory to stimulation by either tumor-conditioned media or various angiogenic factors without interfering with cell proliferation [64]. In addition, there is evidence that the antitumor activity of retinoids involves inhibition of tumor-induced angiogenesis [64-66].

Interactions between retinoid signaling and Prox 1 expression have been described during other aspects of development. RA modulates Prox 1 expression in the dorsal endoderm of mouse embryos [67] and promotes neuronal progenitor cell differentiation into retinal [68] or cochlear cells [69], which express Prox1 [69-72]. Development of the murine liver also appears to be RA dependent [73] 
and Prox 1 is a marker for rat and mouse hepatocytes [67, 74]. Moreover, RA, Prox 1 and RALDH 2 all have important roles in pancreas development $[67,75]$.

Now, retinoid signaling is shown to mediate the earliest steps of lymphatic vasculature development - the acquisition of lymphatic competence and commitment via expression of LYVE-1 and Prox1. It will be important to determine whether retinoids also modulate postnatal lymphangiogenesis, such as the growth of new lymphatic vessels during tissue regeneration and cancer progression [2].

\section{Acknowledgments}

This work was supported by National Institutes of Health grants CA69184 and CA86410, Swiss National Science Foundation grant 3100A0-108207, Austrian Science Foundation grant S9408-B11, Cancer League Zurich, Oncosuisse and Commission of the European Communities grant LSHC-CT-2005-518178 (M.D.).

\section{References}

1 Alitalo K, Tammela T, Petrova TV: Lymphangiogenesis in development and human disease. Nature 2005;438:946-953.

2 Cueni LN, Detmar M: The lymphatic system in health and disease. Lymphat Res Biol 2008;6:109-122.

>3 Hirakawa S, Brown LF, Kodama S, Paavonen K, Alitalo K, Detmar M: VEGF-C-induced lymphangiogenesis in sentinel lymph nodes promotes tumor metastasis to distant sites. Blood 2007;109:1010-1017.

4 Hirakawa S, Kodama S, Kunstfeld R, Kajiya K, Brown LF, Detmar M: VEGF-A induces tumor and sentinel lymph node lymphangiogenesis and promotes lymphatic metastasis. J Exp Med 2005;201:1089-1099.

5 Rinderknecht M, Detmar M: Tumor lymphangiogenesis and melanoma metastasis. J Cell Physiol 2008;216:347-354.

6 Jurisic G, Detmar M: Lymphatic endothelium in health and disease. Cell Tissue Res 2009;335:97-108.

7 Kerjaschki D: Lymphatic neoangiogenesis in renal transplants: a driving force of chronic rejection? J Nephrol 2006;19:403-406.

$\checkmark 8$ Oliver G: Lymphatic vasculature development. Nat Rev Immunol 2004;4:35-45.

$\checkmark 9$ Huang SS, Liu IH, Smith T, Shah MR, Johnson FE, Huang JS: CRSBP-1/LYVE-1-null mice exhibit identifiable morphological and functional alterations of lymphatic capillary vessels. FEBS Lett 2006;580:6259-6268.

10 Gale NW, Prevo R, Espinosa J, Ferguson DJ, Dominguez MG, Yancopoulos GD, Thurston G, Jackson DG: Normal lymphatic development and function in mice deficient for the lymphatic hyaluronan receptor LYVE-1. Mol Cell Biol 2007;27:595-604.

-11 Wigle JT, Harvey N, Detmar M, Lagutina I, Grosveld G, Gunn MD, Jackson DG, Oliver G: An essential role for PROX1 in the induction of the lymphatic endothelial cell phenotype. EMBO J 2002;21:1505-1513.
12 Karkkainen MJ, Haiko P, Sainio K, Partanen J, Taipale J, Petrova TV, Jeltsch M, Jackson DG, Talikka M, Rauvala H, Betsholtz C, Alitalo K: Vascular endothelial growth factor $\mathrm{C}$ is required for sprouting of the first lymphatic vessels from embryonic veins. Nat Immunol 2004;5:74-80.

13 Francois M, Caprini A, Hosking B, Orsenigo F, Wilhelm D, Browne C, Paavonen K, Karnezis T, Shayan R, Downes M, Davidson T, Tutt D, Cheah KS, Stacker SA, Muscat GE, Achen MG, Dejana E, Koopman P: Sox18 induces development of the lymphatic vasculature in mice. Nature 2008;456:643-647.

-14 Abtahian F, Guerriero A, Sebzda E, Lu MM, Zhou R, Mocsai A, Myers EE, Huang B, Jackson DG, Ferrari VA, Tybulewicz V, Lowell CA, Lepore JJ, Koretzky GA, Kahn ML: Regulation of blood and lymphatic vascular separation by signaling proteins SLP-76 and SYK. Science 2003;299:247-251.

-15 Sebzda E, Hibbard C, Sweeney S, Abtahian F, Bezman N, Clemens G, Maltzman JS, Cheng L, Liu F, Turner M, Tybulewicz V, Koretzky GA, Kahn ML: SYK and SLP-76 mutant mice reveal a cell-autonomous hematopoietic cell contribution to vascular development. Dev Cell 2006;11:349-361.

-16 Taniguchi K, Kohno R, Ayada T, Kato R, Ichiyama K, Morisada T, Oike Y, Yonemitsu Y, Maehara Y, Yoshimura A: Spreds are essential for embryonic lymphangiogenesis by regulating vascular endothelial growth factor receptor 3 signaling. Mol Cell Biol 2007; 27:4541-4550.

-17 Backhed F, Crawford PA, O’Donnell D, Gordon JI: Postnatal lymphatic partitioning from the blood vasculature in the small intestine requires fasting-induced adipose factor. Proc Natl Acad Sci USA 2007;104:606611.

18 Petrova TV, Karpanen T, Norrmen C, Mellor R, Tamakoshi T, Finegold D, Ferrell R, Kerjaschki D, Mortimer P, Yla-Herttuala S, Miura N, Alitalo K: Defective valves and abnormal mural cell recruitment underlie lymphatic vascular failure in lymphedema distichiasis. Nat Med 2004;10:974-981.
19 Gale NW, Thurston G, Hackett SF, Renard R, Wang Q, McClain J, Martin C, Witte C, Witte MH, Jackson D, Suri C, Campochiaro PA, Wiegand SJ, Yancopoulos GD: Angiopoietin-2 is required for postnatal angiogenesis and lymphatic patterning, and only the latter role is rescued by angiopoietin-1. Dev Cell 2002;3:411-423.

-20 Shimoda H, Bernas MJ, Witte MH, Gale NW, Yancopoulos GD, Kato S: Abnormal recruitment of periendothelial cells to lymphatic capillaries in digestive organs of angiopoietin-2-deficient mice. Cell Tissue Res 2007; 328:329-337.

21 Yuan L, Moyon D, Pardanaud L, Breant C, Karkkainen MJ, Alitalo K, Eichmann A: Abnormal lymphatic vessel development in neuropilin 2 mutant mice. Development 2002;129:4797-4806.

22 Makinen T, Adams RH, Bailey J, Lu Q, Ziemiecki A, Alitalo K, Klein R, Wilkinson GA: $\mathrm{PDZ}$ interaction site in ephrinB2 is required for the remodeling of lymphatic vasculature. Genes Dev 2005;19:397-410.

-23 Schacht V, Ramirez MI, Hong YK, Hirakawa S, Feng D, Harvey N, Williams M, Dvorak AM, Dvorak HF, Oliver G, Detmar M: T1 $\alpha /$ podoplanin deficiency disrupts normal lymphatic vasculature formation and causes lymphedema. EMBO J 2003;22:3546-3556.

24 Liersch R, Nay F, Lu L, Detmar M: Induction of lymphatic endothelial cell differentiation in embryoid bodies. Blood 2006;107:12141216 .

-25 Kreuger J, Nilsson I, Kerjaschki D, Petrova T, Alitalo K, Claesson-Welsh L: Early lymph vessel development from embryonic stem cells. Arterioscler Thromb Vasc Biol 2006; 26:1073-1078.

26 Lohnes D, Mark M, Mendelsohn C, Dolle P, Decimo D, LeMeur M, Dierich A, Gorry P, Chambon P: Developmental roles of the retinoic acid receptors. J Steroid Biochem Mol Biol 1995;53:475-486. 
27 White J, Highland M, Clagett-Dame M: Abnormal development of the sinuatrial venous valve and posterior hindbrain may contribute to late fetal resorption of vitamin A-deficient rat embryos. Teratology 2000;62:374384.

28 White JC, Shankar VN, Highland M, Epstein ML, DeLuca HF, Clagett-Dame M: Defects in embryonic hindbrain development and fetal resorption resulting from vitamin a deficiency in the rat are prevented by feeding pharmacological levels of all-trans-retinoic acid. Proc Natl Acad Sci USA 1998;95:13459_13464.

29 Kurosawa H: Methods for inducing embryoid body formation: in vitro differentiation system of embryonic stem cells. J Biosci Bioeng 2007;103:389-398.

-30 Brandli AW, Kirschner MW: Molecular cloning of tyrosine kinases in the early Xenopus embryo: identification of ECK-related genes expressed in cranial neural crest cells of the second (hyoid) arch. Dev Dyn 1995; 203:119-140.

- 31 Helbling PM, Saulnier DM, Robinson V, Christiansen JH, Wilkinson DG, Brandli AW: Comparative analysis of embryonic gene expression defines potential interaction sites for Xenopus EphB4 receptors with ephrin-B ligands. Dev Dyn 1999;216:361-373.

32 Helbling PM, Tran CT, Brandli AW: Requirement for EphA receptor signaling in the segregation of Xenopus third and fourth arch neural crest cells. Mech Dev 1998;78:63-79.

33 Saulnier DM, Ghanbari H, Brandli AW: Essential function of WNT-4 for tubulogenesis in the Xenopus pronephric kidney. Dev Biol 2002;248:13-28.

-34 Hatzopoulos AK, Folkman J, Vasile E, Eiselen GK, Rosenberg RD: Isolation and characterization of endothelial progenitor cells from mouse embryos. Development 1998; 125:1457-1468.

- 35 Drab M, Haller H, Bychkov R, Erdmann B, Lindschau C, Haase H, Morano I, Luft FC, Wobus AM: From totipotent embryonic stem cells to spontaneously contracting smooth muscle cells: a retinoic acid and dbcamp in vitro differentiation model. FASEB J 1997;11:905-915.

-36 Lang E, Mazauric-Stuker ML, Maelicke A: States of developmental commitment of a mouse embryonal carcinoma cell line differentiating along a neural pathway. J Cell Biol 1989;109:2481-2493.

- 37 Chan BW, Chan KS, Koide T, Yeung SM, Leung MB, Copp AJ, Loeken MR, Shiroishi T, Shum AS: Maternal diabetes increases the risk of caudal regression caused by retinoic acid. Diabetes 2002;51:2811-2816.

38 Dawid IB, Sargent TD: Xenopus laevis in developmental and molecular biology. Science 1988;240:1443-1448.
39 Ny A, Koch M, Schneider M, Neven E, Tong RT, Maity S, Fischer C, Plaisance S, Lambrechts D, Heligon C, Terclavers S, Ciesiolka M, Kalin R, Man WY, Senn I, Wyns S, Lupu F, Brandli A, Vleminckx K, Collen D, Dewerchin M, Conway EM, Moons L, Jain RK, Carmeliet P: A genetic Xenopus laevis tadpole model to study lymphangiogenesis. Nat Med 2005;11:998-1004.

40 Kalin RE, Banziger-Tobler NE, Detmar M, Brandli AW: An in vivo chemical library screen in Xenopus tadpoles reveals novel pathways involved in angiogenesis and lymphangiogenesis. Blood 2009;114:1110-1122.

41 Banziger-Tobler NE, Halin C, Kajiya K Detmar M: Growth hormone promotes lymphangiogenesis. Am J Pathol 2008;173: 586-597.

42 Bjorndahl M, Cao R, Nissen LJ, Clasper S Johnson LA, Xue Y, Zhou Z, Jackson D, Hansen AJ, Cao Y: Insulin-like growth factors 1 and 2 induce lymphangiogenesis in vivo. Proc Natl Acad Sci USA 2005;102:1559315598.

43 Al-Rawi MA, Watkins G, Mansel RE, Jiang WG: The effects of interleukin-7 on the lymphangiogenic properties of human endothelial cells. Int J Oncol 2005;27:721-730.

44 Sabin F: On the origin of the lymphatics system from the veins and the development of the lymph hearts and the thoracic duct in the pig. Am J Anat 1902;1:367-389.

45 Huntington GS, McClure CFW: The anatomy and development of the jugular lymph sac in the domestic cat (Felis domestica). Am J Anat 1910;10:177-312.

46 Srinivasan RS, Dillard ME, Lagutin OV, Lin FJ, Tsai S, Tsai MJ, Samokhvalov IM, Oliver $\mathrm{G}$ : Lineage tracing demonstrates the venous origin of the mammalian lymphatic vasculature. Genes Dev 2007;21:2422-2432.

47 Wilting J, Tomarev SI, Christ B, Schweigerer L: Lymphangioblasts in embryonic lymphangiogenesis. Lymphat Res Biol 2003;1:3340

48 Wilting J, Papoutsi M, Othman-Hassan K, Rodriguez-Niedenfuhr M, Prols F, Tomarev SI, Eichmann A: Development of the avian lymphatic system. Microsc Res Tech 2001;55: 81-91.

49 Apfel C, Bauer F, Crettaz M, Forni L, Kamber M, Kaufmann F, LeMotte P, Pirson W, Klaus M: A retinoic acid receptor alpha antagonist selectively counteracts retinoic acid effects. Proc Natl Acad Sci USA 1992;89: 7129-7133.

50 Gaillard E, Bruck N, Brelivet Y, Bour G, Lalevee S, Bauer A, Poch O, Moras D, RochetteEgly C: Phosphorylation by PKA potentiates retinoic acid receptor alpha activity by means of increasing interaction with and phosphorylation by cyclin H/CDK7. Proc Natl Acad Sci USA 2006;103:9548-9553.

- 51 Lammer E, Chen D, Hoar R, Agnish N, Benke P, Braun J, Curry C, Fernhoff P, Grix A, Lott I: Retinoic acid embryopathy. N Engl J Med 1986;315:262-263.
52 Radhika MS, Bhaskaram P, Balakrishna N, Ramalakshmi BA, Devi S, Kumar BS: Effects of vitamin a deficiency during pregnancy on maternal and child health. BJOG 2002;109: 689-693

53 Clagett-Dame M, DeLuca HF: The role of vitamin a in mammalian reproduction and embryonic development. Annu Rev Nutr 2002;22:347-381.

54 Kochhar DM: Teratogenetic activity of retinoic acid. Acta Pathol Microbiol Scand 1967; 70:398-404.

55 Moro Balbas JA, Gato A, Alonso Revuelta MI, Pastor JF, Repressa JJ, Barbosa E: Retinoic acid induces changes in the rhombencephalic neural crest cells migration and extracellular matrix composition in chick embryos. Teratology 1993;48:197-206.

56 Ozeki H, Shirai S: Developmental eye abnormalities in mouse fetuses induced by retinoic acid. Jpn J Ophthalmol 1998;42:162-167.

57 Quemelo PR, Lourenco CM, Peres LC: Teratogenic effect of retinoic acid in Swiss mice. Acta Cir Bras 2007;22:451-456.

58 Duester G: Retinoic acid synthesis and signaling during early organogenesis. Cell 2008;134:921-931

59 Manshouri T, Yang Y, Lin H, Stass SA, Glassman AB, Keating MJ, Albitar M: Downregulation of rar alpha in mice by antisense transgene leads to a compensatory increase in RAR $\beta$ and RAR $\gamma$ and development of lymphoma. Blood 1997;89:2507-2515.

-60 Canon E, Cosgaya JM, Scsucova S, Aranda A: Rapid effects of retinoic acid on CREB and ERK phosphorylation in neuronal cells. Mol Biol Cell 2004; 15:5583-5592.

61 Koide T, Downes M, Chandraratna RA, Blumberg B, Umesono K: Active repression of RAR signaling is required for head formation. Genes Dev 2001;15:2111-2121.

62 Saito A, Sugawara A, Uruno A, Kudo M, Kagechika H, Sato Y, Owada Y, Kondo H, Sato M, Kurabayashi M, Imaizumi M, Tsuchiya S, Ito S: All-trans retinoic acid induces in vitro angiogenesis via retinoic acid receptor: possible involvement of paracrine effects of endogenous vascular endothelial growth factor signaling. Endocrinology 2007; 148:1412-1423.

63 Gaetano C, Catalano A, Illi B, Felici A, Minucci S, Palumbo R, Facchiano F, Mangoni A, Mancarella S, Muhlhauser J, Capogrossi MC: Retinoids induce fibroblast growth factor-2 production in endothelial cells via retinoic acid receptor $\alpha$ activation and stimulate angiogenesis in vitro and in vivo. Circ Res 2001;88:E38-E47.

64 Lingen MW, Polverini PJ, Bouck NP: Inhibition of squamous cell carcinoma angiogenesis by direct interaction of retinoic acid with endothelial cells. Lab Invest 1996;74:476483. 
65 Oikawa T, Hirotani K, Nakamura O, Shudo K, Hiragun A, Iwaguchi T: A highly potent antiangiogenic activity of retinoids. Cancer Lett 1989;48:157-162.

66 Majewski S, Marczak M, Szmurlo A, Jablonska S, Bollag W: Retinoids, interferon $\alpha$, 1,25-dihydroxyvitamin D3 and their combination inhibit angiogenesis induced by nonHPV-harboring tumor cell lines. RAR $\alpha$ mediates the antiangiogenic effect of retinoids. Cancer Lett 1995;89:117-124.

67 Burke Z, Oliver G: Prox1 is an early specific marker for the developing liver and pancreas in the mammalian foregut endoderm. Mech Dev 2002;118:147-155.

-68 Zhao X, Liu J, Ahmad I: Differentiation of embryonic stem cells into retinal neurons. Biochem Biophys Res Commun 2002;297: 177-184.
-69 Bermingham-McDonogh O, Oesterle EC, Stone JS, Hume CR, Huynh HM, Hayashi T: Expression of Proxl during mouse cochlear development. J Comp Neurol 2006;496:172186.

70 Dyer MA: Regulation of proliferation, cell fate specification and differentiation by the homeodomain proteins Prox1, Six3, and Chx10 in the developing retina. Cell Cycle 2003;2:350-357.

71 Tomarev SI, Sundin O, Banerjee-Basu S, Duncan MK, Yang JM, Piatigorsky J: Chicken homeobox gene Prox 1 related to drosophila prospero is expressed in the developing lens and retina. Dev Dyn 1996;206: 354-367.

72 Wigle JT, Chowdhury K, Gruss P, Oliver G: Proxl function is crucial for mouse lens-fibre elongation. Nat Genet 1999;21:318-322.
3 Ogura Y, Suruga K, Mochizuki H, Yamamoto T, Takase S, Goda T: Postnatal changes in gene expression of retinal dehydrogenase and retinoid receptors in liver of rats. Life Sci 2004;74:1519-1528.

74 Dudas J, Elmaouhoub A, Mansuroglu T, Batusic D, Tron K, Saile B, Papoutsi M, Pieler T, Wilting J, Ramadori G: Prospero-related homeobox 1 (Prox1) is a stable hepatocyte marker during liver development, injury and regeneration, and is absent from 'oval cells'. Histochem Cell Biol 2006;126:549-562.

75 Molotkov A, Molotkova N, Duester G: Retinoic acid generated by Raldh2 in mesoderm is required for mouse dorsal endodermal pancreas development. Dev Dyn 2005;232: 950-957. 